\title{
OPIEKA SPOLECZNA U PROTESTANTÓW W POLSCE W XVI-XVIII WIEKU
}

\section{Wstęp}

Formy świadczenia pomocy ludziom potrzebującym zmieniały się w zależności od czasu i konkretnej sytuacji, zależały np. od systemów ustrojowych, filozoficznych czy religii. Od początku chrześcijaństwa aż do Oświecenia działalność charytatywną prowadzono w szpitalach, stanowiących podstawową i najbardziej rozpowszechnioną formę sprawowania opieki społecznej. W dawnych czasach szpital był w zasadzie przytułkiem, posiadającym charakter socjalno-opiekuńczy, a niej jak obecnie infirmeryczno-leczniczy. Opiekę organizowaną w szpitalach można określić mianem zinstytucjonalizowanej. Jej uzupełnieniem były inne formy wsparcia ze strony stowarzyszeń religijnych i świeckich, chociażby bractw charytatywnych, cechów. W średniowieczu inicjatywa w zakresie organizowania dobroczynności należała przede wszystkim do Kościoła. Słaba urbanizacja i silna pozycja polskiego Kościoła katolickiego sprawiły, że w Rzeczpospolitej nie zyskały poważniejszego odzewu dyskutowane w XVI w. zwłaszcza w krajach protestanckich, postulaty oddania szpitali pod nadzór miast oraz przymusowego zatrudnienia zdrowych żebraków. System opieki społecznej w Rzeczpospolitej w czasach nowożytnych był nadal tradycyjny i kościelny, w dużym stopniu bazujący na średniowiecznej koncepcji dobroczynności. Bardziej podobny był do istniejącego w państwach arcykatolickich, jak Hiszpania i Państwo Kościelne, niż do występującego w krajach zurbanizowanych i rozwiniętych, o dużych wpływach reformacyjnych i silnej władzy centralnej, nieraz absolutnej (Anglia, Niderlandy, Francja, protestanckie kraje niemieckie).

W Polsce protestanckie rozwiązania w opiece zaznaczyły się mocniej w Prusach Królewskich i istniejących tam większych miastach,

„Nasza Przeszłość” t. 132: 2019, s. 127-180. 
ogarniętych wpływami reformacji, która wprowadziła inny, bardziej miejski, model opieki społecznej. Miłosierdzie w rozumieniu protestanckim polegało na stwarzaniu szans samopomocy ludziom potrzebującym, a nie jak w katolicyzmie, doraźnej, gotowej, pomocy materialnej, szpitalnej lub innej. Wpływy systemu opieki niderlandzkiej czy niemieckiej wyraźnie zaznaczyły się w takich miastach, jak Toruń (kalwińskie), czy Gdańsk, Elbląg (luterańskie).

Użyte w tytule pojęcie opieka społeczna posiada charakter umowny i roboczy. W rozumieniu dzisiejszym termin ten pojawia się u schyłku czasów nowożytnych, dokładniej w Oświeceniu, kiedy opiekę zaczęto pojmować jako czysto socjalny obowiązek państwa w stosunku do swoich obywateli ${ }^{1}$. W tym samym czasie zaczyna funkcjonować również pojęcie filantropii, oznaczającej pomoc potrzebującym z motywów humanitarnych i solidarności ludzkiej. Nawet w Gdańsku, gdzie nowe idee w dziedzinie opiekuńczej wdrażano wcześniej, do filantropii wzywano dopiero od końca XVII w. i to na drugim miejscu równolegle z miłosierdziem chrześcijańskim ${ }^{2}$. Tak na dobre słowo filantropia pojawiło się w terminologii dopiero w XVIII wieku ${ }^{3}$.

Na tle dotychczasowej historiografii polskiej niniejszy artykuł ma charakter pionierski. Ujmuje całokształt działalności różnorodnych instytucji opiekuńczych i nieinstytucjonalnych inicjatyw dobroczynnych podejmowanych przez środowiska protestanckie w łonie samych współwyznawców. Chodzi niejako o „samopomoc”, pojmowaną jako wewnętrzne zamartwianie się społeczności gmin wyznaniowych o swoich braci. W obliczu barier wyznaniowo-religijnych prawie że niemożliwa była opieka ze strony ewangelików w odniesieniu do potrzebujących pomocy spoza tych grup wyznaniowych. Formy i stan opieki społecznej u protestantów na ziemiach polskich nie były jednolite i bardzo się różniły, dlatego problem ten można rozpatrywać oddzielnie w odniesieniu do poszczególnych wyznań reformacyjnych (luteranie, kalwini, bracia czescy, bracia polscy).

Intencją autora było stworzenie zwartego i syntetycznego ujęcia dziejów opieki społecznej w środowiskach protestanckich w oparciu o istniejący, bardzo rozproszony stan badań, wypracowany w ciągu

\footnotetext{
${ }^{1}$ A. P a z z i n i, L'ospedale nei secoli, Roma 1958, s. 218-221.

2 Por. Z. K r o p i dło w s k i, Realizacja miłosierdzia chrześcijańskiego $w$ działalności kas samopomocowych cechów gdańskich (XVI-XVIII w.), SG, 8, 1992, s. 127.

${ }^{3}$ B. G e r e m e k, Litość i szubienica. Dzieje nędzy i miłosierdzia, Warszawa 1989, s. 213.
} 
ok. ostatnich stu lat. Przy takim założeniu w artykule tym źródła z natury rzeczy stanowią tylko uzupełnienie bazy informacyjnej, która służyła do opracowania zawartej w nim treści.

Silne antagonizmy występujące między katolikami a protestantami, często wzajemna wrogość, podsycana w okresie kontrreformacji szczególnie przez tych pierwszych, spowodowały, że nawet bieda, starość czy choroba nie były w stanie połączyć w jednym miejscu potrzebujących wyznawców obu stron. Wobec tego, zarówno na Zachodzie Europy, jak i w Polsce szpitale stawały się w czasach nowożytnych instytucjami wyznaniowymi, do których przyjmowano wiernych określonego obrządku. Szpitale katolickie, pozostające pod władzą biskupów, były niedostępne dla innowierców, którzy tworzyli dla swoich współwyznawców odrębne zakłady dobroczynne ${ }^{4}$. Dotyczyło to każdej protestanckiej konfesji występującej na terytorium państwa polskiego, a więc luteranów, kalwinów, braci czeskich i arian.

Tylko niezmiernie rzadko i to w wyjątkowych sytuacjach, np. podczas epidemii czy wojen, bariery wyznaniowe w szpitalach bywały przełamywane. Zdarzyło się tak np. w lazarecie w Pieniężnie, do którego w XVIII w. przyjmowano katolików i niekatolików potrzebujących pomocy ${ }^{5}$. W tym wypadku przyczyną takiego ,altruizmu” był lęk przed śmiertelnym zagrożeniem ze strony zadżumionych i konieczność ich izolacji bez względu na wyznawaną wiarę. Ze szczególnej tolerancji religijnej zasłynęli bonifratrzy, którzy w swych szpitalach leczyli chorych i rannych innych narodowości. W ich krakowskiej lecznicy przebywało w czasie potopu, a następnie wojny północnej wielu luterańskich żołnierzy szwedzkich. Podobnie rzecz się miała w szpitalach bonifraterskich w Wilnie, Grodnie, gdzie pełno było niemieckich żołnierzy innowierców ${ }^{6}$.

\footnotetext{
${ }^{4}$ L. W a c h h o l z, Szpitale krakowskie 1220-1920, t. 1, Kraków 1921, s. 37; T e n ż e, O szpitalach innowierców w Krakowie. Szkic historyczny, „Archiwum Filozofii i Historii Medycyny, 2, 1925, s. 173; Z. B u dzyń s k i, Dzieje opieki społecznej w ziemi przemyskiej i sanockiej (XV-XVIII w.), Przemyśl-Kraków 1987, s. 80; Z. G ó r a 1 s k i, Szpitale na Lubelszczyźnie w okresie przedrozbiorowym w okresie przedrozbiorowym, Warszawa-Łódź 1982 s. 46.

5 A. K o p i c z ko, Szpitalnictwo na Warmii w XVI-XVIII wieku, [w:] Szpitalnictwo w dawnej Polsce, red. M. D ą b r o w s k a, J. K r u p p é, Warszawa 1998, s. 103.

${ }^{6} \mathrm{H}$. K o m a r y ń s k a, Szpital Bonifratrów w Krakowie $w$ XVII XVIII wieku, Lublin 2010, s. 239, 244, 262-263; S. R o s i a k, Bonifratrzy w Wilnie (1635-1835-1924). Szkice z dziejów opieki społecznej w Wilnie, Wilno 1928, s. 77-82.
} 
Nie da się jednoznacznie rozsądzić, czy sporadyczna obecności innowierców w szpitalach katolickich wynikała $\mathrm{z}$ chrześcijańskiego miłosierdzia czy z walki o „dusze ludzkie”, która obejmowała również teren placówek charytatywnych. Człowieka chorego, starego i słabego, stojącego w obliczu śmierci, łatwiej było nawrócić na ,prawdziwą wiarę" niż młodego, zdrowego i silnego. Pierwszą z wymienionych opcji uwiarygodnia zapis w aktach wizytacji parafii Swarzędz z 1695 r., z którego wynika, że pleban lub wikary mają prawo i obowiązek odwiedzania chorych sekty luterańskiej (infirmos lutheranae sectae tempore infirmitatis). Zdaniem wizytatora nie powinni oni być $\mathrm{w}$ takich momentach $\mathrm{z}$ dala od swoich błądzących ubogich braci, a wtedy być może łaska Boża sprawi, że nawrócą się na wiarę katolicką ${ }^{7}$ Na terenie placówek charytatywnych trwała także „walka o duszę” najmłodszych. Toczyli ją np. jezuici w prowadzonym przez siebie w drugiej połowie XVIII domu sierot w Ustroniu na ogarniętym wpływem reformacji luterańskiej Śląsku Cieszyńskim. Do placówki trafiały zarówno naturalne sieroty, niektóre protestanckie dzieci posiadające rodziców oraz dzieci z rodzin mieszanych, którym groziło odłączenie od wiary katolickiej. Te ostatnie określano jako „źle wychowane" (male educati). Historia ustrońskiego przytułku kojarzona jest głównie z rekatolizacyjną działalnością jezuitów i na wracaniem na wiarę dzieci protestantów ${ }^{8}$.

\section{Luteranie}

Spośród wyznań reformowanych najwcześniej w państwie polskim pojawił się luteranizm. Ze względu na rodowód i język, w którym był propagowany, religia Lutra korzeniła się na terenach i w miastach o dużych skupiskach ludności niemieckiej. Luteranie, inaczej ewangelicy augsburscy, byli więc najmocniejsi w Wielkopolsce ${ }^{9}$, na Pomorzu

\footnotetext{
${ }^{7}$ Archiwum Archidiecezjalne w Poznaniu (AAP), AV 18, Visitatio archidiaconatus Posnanensis [...] a Nicolao Zalaszowski archidiacono Posnaniensi. Anno Domini 1695-1696 expedita, s. 605; M. S u r d a c k i, Opieka spoleczna w Wielkopolsce Zachodniej w XVII-XVIII wieku, Lublin 1992, s. 174-175; T e n ż e, Sieć szpitali łacińskich w Rzeczypospolitej w XVI-XVIII wieku, „Nasza Przeszłość”, 123, 2015, s. 204.

${ }^{8}$ M. T. B a k, Dom sierot $w$ Ustroniu $w$ latach 1735-1787, Lublin 2010 (mps, Archiwum KUL), s. 5, 23, 29, 39. Zob. też, B. P o l o c z k o w a, Dokumenty Domu Sierot w Ustroniu, „Pamiętnik Cieszyński”, 14, 1999, s. 94-109.

9 J. Le wi cki, Stosunki wyznaniowe $w$ wielkopolskiej częśsi diecezji poznańskiej $w$ drugiej połowie XVIII w., [w:] Z badań nad dziejami zakonów i stosunków wyznaniowych $w$ Polsce, red. E. W i ś n i o w s k i, Lublin 1984, s. 89-138.
} 
Gdańskim oraz na niektórych terenach śląskich (księstwa oświęcimskie i zatorskie $)^{10}$. O germańskim podłożu luteranizmu świadczy fakt, że na 140 zborów augsburskich istniejących w 1591 r. w Wielkopolsce aż 110 było zborami niemieckimi ${ }^{11}$. Generalnie luteranizm na ziemiach polskich był wyznaniem etnicznie i kulturowo obcym, religią mieszczan niemieckich zamieszkujących w aglomeracjach miejskich Prus Królewskich (Gdańsku, Elblągu, Toruniu) ${ }^{12}$, licznych miasteczkach wielkopolskich oraz kilku innych, dużych miastachenklawach ludności niemieckiej (Kraków, Wilno, Kowno, później Warszawa) ${ }^{13}$. W Prusach Królewskich luteranizm stanowił dla miast czynnik walki o prawa polityczne i samorząd ${ }^{14}$, który miał decydujące znaczenie w organizowaniu opieki społecznej i szpitalnictwa. Mieszczanie polscy, a szczególnie chłopi w strukturze ewangelików augsburskich byli mniejszością. Nieobecność chłopów w Kościele luterańskim, wynikała z obojętności szlachty wobec tego wyznania.

$\mathrm{Na}$ opiekę społeczną w Kościele augsburskim na ziemiach polskich wpływały założenia doktrynalno-ideologiczne nauki Lutra, który całkowicie podważył tradycyjną koncepcję opieki opartą w głównej mierze o szpitale, prowadzone w Kościele katolickim nade wszystko przez zakony, rzadziej bractwa. Całkowicie też zanegował średniowieczną jałmużnę i żebractwo jako podstawowy środek wspierania ubogich. Jednym z głównych założeń luterańskiej koncepcji opieki

\footnotetext{
${ }^{10} \mathrm{~W}$. U r b a n, Reformacja wśród chłopów w Oświęcimskim, „Odrodzenie i Reformacja w Polsce", 2, 1957, 158; M. W a j s b l u m, O wyznaniowym obliczu protestatntyzmu polskiego $i$ jego postawach społecznych, [w:] Pamiętnik Zjazdu Naukowego im. Jana Kochanowskiego, Kraków 1931, s. 85-86.

${ }^{11}$ M. W a j s bl u m, O wyznaniowym obliczu, s. 86. Zob. też: J. W i j a c z k a, Luteranie w Koronie od 1517 do 1795 r., [w:] Kościót luterański na ziemiach polskich (XVI-XX w.) w czasach Rzeczypospolitej Obojga Narodów, red. J. Kła c z k o w, Toruń 2012, s. 14, 17-18.

12 S. S a 1 m o n ow i c z, Życie luteranów toruńskich, w XVII i XVIII wieku, „Odrodzenie Reformacja w Polsce", 34, 1989, s. 117; J. D w o r z a c z k o w a, Reformacja i kontrreformacja $w$ Wielkopolsce, Poznań 1995, s. 53; H. Z i n s, Rewolta $w$ Elblagu w 1525 r., „Zapiski Historyczne”, 12, 1956, z. 4, s. 7-50; M. K o s m a n, Archiwum Jednoty Litewskiej, „Archeion”, 61, 1974, s. 82-83.

13 J. L e w i c k i, Stosunki wyznaniowe, s. 120-121; M. K o s m a n, Litewska Jednota ewangelicko-reformowana od połowy XVII w. do 1939 r., Opole 1986, s. 6, 19-20; tenże, Protestanci i kontrreformacja. Z dziejów tolerancji $w$ Rzeczypospolitej XVIXVIII wieku, Wrocław 1978, s. 20, 94-95.

${ }^{14} \mathrm{M}$. W a j s b l u m, $O$ wyznaniowym obliczu, s. 86.
} 
społecznej było jej zsekularyzowanie i powierzenie pod nadzór władz miast. Rola środowisk religijno- kościelnych u luteranów w tej dziedzinie była drugorzędna i podległa inicjatywom miejskim. Świadczy o tym pismo pastorów toruńskich wystosowane w 1573 r. do władz miejskich, wzywające gminę do skuteczniejszej opieki nad dziećmi nieślubnymi, osobami biednymi i chorymi ${ }^{15}$.

Pomimo, że luteranie wprowadzili wiele nowości w metodach pomocy potrzebującym, to jednak zachowali instytucję szpitala, która nie była aż tak dominującą jak w katolicyzmie. Sprawą organizowania szpitali dla swych wyznawców zajmował się luterański konsystorz prowincjonalny w Lesznie ${ }^{16}$.

Istniały dwie grupy szpitali luterańskich. Pierwszą stanowiły szpitale tworzone od podstaw przez ewangelików w momencie organizowania zborów lub w jakiś czas po tym. Takim był szpital ewangelicki w Lesznie, założony w 1547 r. przez protektorów reformacji Leszczyńskich $^{17}$. Przez ponad stu lat był jedyną z dwu, obok szpitala braci czeskich, placówek opiekuńczych w mieście ${ }^{18}$. Luterański szpital w Lesznie, położony nieopodal kalwińskiego, działał nadal w czasach wizytacji z 1778 r. ${ }^{19}$. Do drugiej grupy należały szpitale stanowiące schedę po katolikach. Chodzi m.in. o prepozytuty szpitalne i szpitale zakonne ,agregowane” przez zwolenników reformacji po zlikwidowanych lub

$15 \mathrm{~S}$. S a $1 \mathrm{~m}$ o n o w i c z, O reglamentacji obyczajowości mieszczańskiej $w$ Toruniu w XVI-XVIII wieku (zakres problematyki), ,Zapiski Historyczne”, 41, 1976, z. 3, s. 92.

${ }^{16} \mathrm{~J}$. W i j a c z k a, Luteranie, s. 36.

17 W. Kri e g s e i s e n, Miłosierdzie czy opieka społeczna? Działalność opiekuńcza w Jednocie ewangelicko-reformowanej Wielkiego Księstwa litewskiego w XVIII wieku, [w:] Charitas. Miłosierdzie i opieka społeczna $w$ ideologii, normach postępowania i praktyce spoleczności wyznaniowych w Rzeczypospolitej XV-XVIII wieku, red. U. A u g u st y n i a k, A. K ar p ińs k i, Warszawa 1999, s. 118; J. D w or z a c z k ow a, Bracia czescy $w$ Wielkopolsce $w$ XVI $i$ XVII wieku, Warszawa 1997, s. 53, 156; E. B y r t e k, Miłosierdzie i opieka społeczna w osiemnastowiecznym pietyźmie, [w:] Charitas. Miłosierdzie i opieka spoleczna..., s. 77.

18 M. S u rd a c ki, Opieka społeczna, s. 35, 50, 59; T e nż e, Protestanci a rozwój szpitali w Wielkopolsce Zachodniej w XVII i XVIII wieku, „Odrodzenie i Reformacja w Polsce", 36, 1991, s. 200.

19 AAP, AV 33, Visitatio generalis archidiconatus Śremensis: Śmigiel, Wschowa, Koźmin, Krobia aucthoritate Andreae Stanislai Młodziejowski et Antonii Onuphri Okęcki episcoporum Posnaniensium \{...\} Anno Domini 1777-1783 expedita, s. 209. W Lesznie mieszkało wtedy 4918 luteranów i kalwinistów, 3000 Żydów oraz 1214 katolików, tamże s. 205v, 209. 
wyrugowanych zakonach. Sytuacja taka miała miejsce w Dzierżoniowie, Ząbkowicach Śląskich ${ }^{20}$.

Pojawia się pytanie o szpitale w „sprotestantyzowanej” Wielkopolsce. Utrata przez katolików kościoła parafialnego na rzecz protestantów wykluczała definitywnie aż do momentu rekatolicyzacji istnienie szpitala katolickiego $\mathrm{w}$ parafii, czy jednak dawała szansę na stworzenie analogicznej placówki innowierczej? Akta wizytacji biskupich, z wyjątkiem wspomnianego Leszna, nie mówią nic o luterańskich placówkach dobroczynnych, bowiem parafie ewangelickie wyłączone były spod opisu wizytacyjnego. W byłych parafiach luterańskich, w których po przywróceniu ich do Kościoła katolickiego z reguły szybko powstawał przytułek parafialny, nie ma wzmianek by został on odziedziczony po ewangelikach ${ }^{21}$.

Co innego, gdy chodzi o powstałe w średniowieczu prepozytury szpitalne, które przetrwały okres reformacji. Niektóre z nich, przechodząc w XVI w. wraz z parafią w posiadanie innowierców, czasowo nie funkcjonowały, ale gdy tylko nastąpiła rekatolicyzacja kościoła parafialnego, wznawiały swoją działalność. Prepozytura szpitalna w Międzyrzeczu za panowania Zygmunta Augusta pozostawała w rękach luteranów i dopiero w r. 1603 razem z parafią została zwrócona katolikom $^{22}$. Luteranie międzyrzeccy nadal jednak posiadali szpital ewangelicki $^{23}$. Zdarzało się też, jak choćby w Skwierzynie, że po przejęciu parafii przez protestantów szpital prepozyturalny był przeznaczony na cele opieki społecznej nad biednymi innowiercami ${ }^{24}$.

Stare średniowieczne szpitale przejęte wraz z nastaniem reformacji przez luteranów spod zarządu Kościoła katolickiego stanowiły odrębną grupę placówek opiekuńczych. Było ich wiele w miastach o przewadze

${ }^{20}$ K. D o l a, Szpitale średniowieczne Śląska. Rozwój historyczny, „Rocznik Teologiczny Śląska Opolskiego", 1, 1968, s. 267, 290.

${ }^{21}$ M. S u r d a c k i, Opieka spoleczna, s. 29-30, 59; T e n ż e, Protestanci, s. 197.

22 M. S u rd a c ki, Opieka społeczna, s. 30; tenże, Protestanci a szpitale, s. 198; J. Ł u k a s z e w i c z, Krótki opis historyczny kościołów parochialnych, kościołów, kaplic, klasztorów, szkótek parochialnych, szpitali i innych zakładów dobroczynnych dawnej diecezji poznańskiej, t. 1, Poznań 1958, s. 367.

${ }^{23}$ Istniał on na pewno w Międzyrzeczu w 1793 r. J. W ą s i c k i, Miasta zachodniego pogranicza Wielkopolski 1793-1815, Poznań 1960, s. 34.

24 AAP, AV 3, s. 143; M. S u r d a c k i, Opieka spoleczna, s. 30; tenże, Protestanci a szpitale, s. 198. 
ludności luterańskiej, Gdańsku ${ }^{25}$, Toruniu i Elblągu. W największym ośrodku miejskim ówczesnej Rzeczpospolitej Gdańsku stosunek do biednych i opieki społecznej ukształtował się pod wpływem poglądów głoszonych przez Lutra ${ }^{26}$, który ,,przeorientował dobroczynność nakierowaną w średniowieczu na każdego ubogiego, niezależnie od jego statusu, na dobroczynność nakierowaną jedynie na tych ubogich, których ubóstwo nie zostało zawinione, a nędza w jaką popadli, uniemożliwiała im samodzielne funkcjonowanie"27.

Przełomowym dla gdańskiej opieki społecznej był rok 1525, kiedy załamały się jej dotychczasowe formy organizacyjne oparte na działalności Kościoła katolickiego. Od tej pory to ewangelicka rada miejska jako Pierwszy Ordynek wraz z obywatelami przejęła na swoje barki opiekę społeczną i organizację miłosierdzia na zasadach doktryny luterańskiej. Jurysdykcji, luterańskiej rady zaczęły też podlegać związane $\mathrm{z}$ miastem szpitale ${ }^{28}$. Najważniejszym osiągnięciem rady w okresie od XVI do XVIII w. było wydanie czterech ordynacji $(1525,1551$, druga połowa XVI, 1661) i rozporządzeń, którymi normowała ona organizację miłosierdzia. Postanowienia aktów ordynacyjnych aktów stworzyły ramy, w których mieściły się wszystkie formy opieki społecznej nad ubogimi w Gdańsku ${ }^{29}$.

Zmiana organizatora i ,gospodarza” opieki nie spowodowała radykalnych zmian w ilości gdańskich szpitali, a tylko zreformowała sposób ich zarządzania, podniosła poziom obsługi medyczno-lekarskiej i poszerzyła ofertę specjalizacyjną ${ }^{30}$. Nie było to wyłączną zasługą

$25 \mathrm{~Np}$. w ręce gminy luterańskiej przeszedł w 1556 r. przeszedł szpital św. Jakuba w Gdańsku. A. S z a r s z e w s k i, Życie codzienne w szpitalu św. Jakuba w Gdańsku w XVI-XVIII w., [w:] Szpital i kościót św. Jakuba. 600 lat fundacji gildii szyprów w Gdańsku, red. A. S r o k a, Toruń 2009, s. 201.

${ }^{26}$ E. C i e ś 1 a k, Obraz społeczeństwa gdańskiego i jego życia codziennego, [w:] Historia Gdańska, t. III/1: 1655-1793, pod red. E. C i e ś l a k a, Gdańsk 1993, s. 273.

27 A. S z ar s z e w s k i, , Tablica jałmużnicza” Antona Möllera z Kościoła Mariackiego w Gdańsku. Społeczna geneza zabytku, „Rocznik Gdański”, 66, 2006, s. 87.

${ }^{28}$ Z. K r o p i dło w s k i, Formy opieki nad ubogimi w Gdańsku od XVI do XVIII w., Gdańsk 1992, s. 10, 39.

29 Tamże, s. 25-32; T e n ż e, Organizacja dziet miłosierdzia chrześcijańskiego w Gdańsku w XVI-XVIII w., [w:] Charitas. Miłosierdzie i opieka społeczna, s. 140-143; M. B o g u c k a, Dom pracy w Gdańsku $w$ XVII wieku, „Kwartalnik Historii Kultury Materialnej", 34, 1986, nr 2, s. 265-267.

${ }^{30}$ M. B o g u c k a, Organizacja szpitalnictwa w Gdańsku w XVI-XVII wieku, [w:] Szpitalnictwo w dawnej Polsce, red. M. D ą b r o w s k a, J. K r u p p é, Warszawa 1998, s. 152. 
rządów protestanckich, bowiem reformacja gdańska otrzymała w spuściźnie po średniowieczu dziewięć zamożnych, dobrze uposażonych szpitali $^{31}$. Przykładowo w końcu XVI w. najstarszy szpital św. Ducha rozbudowano o tzw. Szpital Tylny, a przy dawnym szpitalu św. Elżbiety w 1542 r. wzniesiono połączony z nim Dom Dziecka ${ }^{32}$. Na konto miejskiej administracji luterańskiej należy natomiast zapisać założenie w 1542 r. szpitala dla chorych psychicznie, wspomnianego Domu Dziecka, Domu Wychowawczego dla młodzieży (1630), lazaretu dla chorych na dżumę (1698), pełniącego funkcje sierocińca i przytułku Domu Dobroczynności (1699), przytułku dla wdów (1724), czy przytułku dla włóczęgów (1788) $)^{33}$.

Na szczególną uwagę zasługuje Dom Wychowawczy (Zuchthaus) inaczej Dom Pracy Przymusowej, pierwsza na terenach Rzeczypospolitej instytucja penitencjarno-charytatywna, a zarazem korekcyjna wzorowana na niderlandzkich i północnoniemieckich domach poprawy i szpitalach generalnych ${ }^{34}$. Etos pracy był podstawą doktryny luterańskiej i związanej z tym wyznaniem opieki społecznej. Stąd istotą i celem działań opiekuńczych u Lutra i ewangelików augsburskich było stworzenie miejsca pracy, a w przypadku dzieci nauka zawodu ${ }^{35}$.

Gdańsk w czasach przedrozbiorowych posiadał niespotykaną w innych miastach, liczbę szpitali. Do rozbiorów erygowano tam 23 krócej lub dłużej trwających fundacji szpitalnych, nie licząc prowizorycznych

${ }^{31}$ A. S z a r s z e w s k i, Najstarsze księgi rachunkowe szpitali gdańskich, Toruń 2005, s. 8; tenże, Ordynacje i statuty szpitali gdańskich XV-XIX w., Toruń 2004, s. 8. Były to szpitale: św. Ducha (połączony w 1546 r. ze szpitalem św. Elżbiety, św. Gertrudy, św. Jerzego, Wszystkich Aniołów Bożych, Bożego Ciała, św. Barbary, św. Elżbiety, św. Jakuba, w. Rocha - przekształcony w 15000 r. w lazaret św. Łazarza).)

${ }^{32}$ M. B o g u c k a, Organizacja, s. 146-147; A. S z a r s z e w s k i, Ordynacje i statuty, s. 11,46 .

${ }^{33}$ Z. K r o p i dło w s k i, Formy opieki nad ubogimi, s. 82, 89, 116, 121-122, 126130, 53; T e n ż e, Organizacja dzieł miłosierdzia, s. 146.

${ }^{34}$ Z. K r o p i d ł o w s k i, Formy opieki nad ubogimi, s. 128-129; A. S z a r s z e w s k i, Ordynacje i instrukcje szpitala św. Łazarza, Szpitala na Zapleczu oraz Domu dla Chorych Zakaźnie w Gdańsku XVII-XVIII w. Toruń 2005, s. 66; D. K a c z o r, Dom poprawy (Zuchthaus) w Gdańsku w XVII-XVIII wieku, „Rocznik Gdański”, 56, 1996, s. 46; M. B o g u c k a, Dom pracy, s. 265-269.

35 Por. K. K o l e n d o - K o r c z a k, Propaganda reform burmistrza Henryka Strobanda $w$ dekoracji sali Rady z 1603 roku w Ratuszu Staromiejskim Torunia, „Zapiski Historyczne, 74, 2009, z. 3, s. 46-47; J. T. M a c i u s z k o, Miłosierdzie w rozumieniu historycznego protestantyzmu, [w:] Charitas. Miłosierdzie i opieka społeczna..., s. 54-57. 
zakładów organizowanych na wypadek epidemii. Ponad połowa z nich powstała w czasach rządów luterańskich. Ilość szpitali szła w parze z ich różnorodnością i specjalizacją. Choć niektóre zachowały formy przytułkowe, wiele innych świadczyło usługi medyczne, stając się dobrze urządzonymi lecznicami z personelem lekarsko-chirurgicznym. Nadto zasłynął Gdańsk jak ośrodek posiadający największą ilość placówek przeznaczonych do opieki i wychowania dzieci oraz młodzieży ${ }^{36}$.

Szpitale i inne domy opieki zarządzane przez luteranów przyjmowały przede wszystkich swoich wyznawców, niekiedy także pozostałych protestantów, w wyjątkowych wypadkach katolików. Główną ich klientelę, zwłaszcza w dużych miastach, stanowiły osoby pochodzenia niemieckiego lub Niemcy. Wywodziły się prawie wyłącznie z ludności miejskiej, szczególnie plebejskiej. Pomimo świeckości szpitalnictwa luterańskiego, życie w szpitalach wyznaczały praktyki religijne, na które składały się modlitwy i udział w nabożeństwach w istniejących przy nich kościołach lub kaplicach ${ }^{37}$.

Od średniowiecza placówkami opiekuńczymi zarządzali szpitalnicy. Pomagały im mistrzynie, później nazywane gospodyniami lub szafarkami. Usługową rolę $\mathrm{w}$ szpitalach odgrywali pachołkowie miejscy, którzy oprócz pilnowania i nadzorowania żebraków na ulicach, mieli pomagać w szpitalach. Zatrudniano też personel pielęgnacyjny i usługowy: pielęgniarki, pielęgniarzy (sanitariuszy), salowe. Z posługą religijną śpieszyli pensjonariuszom kaznodzieje, kantorzy i przewodnicy śpiewu $^{38}$. Do opieki nad chorymi angażowano doktorów medycyny, chirurgów, balwierzy, aptekarzy. Standard opieki medycznej w szpitalach podnosiła rozbudowana sieć aptek publicznych, z których ubodzy leczeni na koszt miasta mogli pobierać leki ${ }^{39}$. Szpitale gdańskie były zupełnie innymi instytucjami niż pozbawione podstawowej obsługi przytułki katolickie i szpitale ewangelików augsburskich. Funkcją medyczną przypominały bardziej szpitale z miast Europy Zachodniej.

\footnotetext{
${ }^{36}$ Z. K r o p i dło w s k i, Formy opieki nad ubogimi, s. 145, 167; M. B o g u c k a, Organizacja, s. 145-146.

37 Z. K r o p i d ł o w s k i, Organizacja dziet miłosierdzia, s. 103-104, 106, 145. Zob. też: E. C i e ś l a k, Obraz społeczeństwa gdańskiego i jego życia codziennego, [w:] Historia Gdańska, t. III/1: 1655-1793, pod red. E. C i e ś l a k a, Gdańsk 1993, s. 273.

${ }^{38}$ Z. K r o p i d ł o w s k i, Formy opieki nad ubogimi, s. 80, 90-94, także 46-48.

39 Tamże, s. 94-103; S. S o k ó 1, Historia gdańskiego cechu chirurgów 1445-1820, Wrocław-Warszawa 1957, s. 108.
} 
W 1546 r. rada miejska podjęła reformę szpitalnictwa gdańskiego, powołując nowy urząd przełożonych szpitalnych. W ramach kolejnych przekształceń z 1606 r. powołano Urząd Dobroczynności, który powstał z połączenia fundacji pięciu szpitali oraz instytucji opieki nad komornikami i żebrakami gdańskimi. Do Urzędu weszli przełożeni zjednoczonych instytucji. Z czasem włączono do Urzędu Dobroczynności przełożonych pozostałych placówek szpitalnych. Urząd posiadał płatnych pracowników: tacowych - kierujących akcją zbiórek na cele dobroczynne i kontrolujący działalność kwestarzy oraz rotmistrzów odpowiedzialnych za spisywanie ubogich na podległych sobie rotach i decydujących o przyznawaniu zasiłku ${ }^{40}$. Zachowano też występujący od dawna urząd wójtów żebraczych, kontrolujących życie gdańskich żebraków ${ }^{41}$. W XVII w., urząd wójta uległ ewolucji, zaczęto go nazywać także pachołkiem miejskim i wójtem ulicznym, a jego działalność od 1610 r. ściśle wiązała się $z$ funkcjonowaniem szpitali ${ }^{42}$

W luterańskim systemie opieki społecznej funkcjonowały „kasy ubogich", pozostające pod nadzorem władz miejskich. Miały one przejmować zsekularyzowany majątek kościelny - zwłaszcza klasztorny, fundacje szpitalne i charytatywne oraz pozyskiwać nowe środki na rzecz ubogich. Zebrane fundusze przeznaczane były na utrzymanie instytucji opiekuńczych i zabezpieczenie pomocy wszystkim potrzebującym. Pomysłodawcą tych instytucji był Marcin Luter. Koncepcja kasy ubogich miała czasami szerszy wymiar, przyjmując formę wspólnej kasy zborowej, służącej zabezpieczeniu wszystkich potrzeb gminy, w tym charytatywnych ${ }^{43}$. Wraz z postępem luteranizmu idea „kasy ubogich”, tzw. „wspólnej kasy” rozpowszechniła się najpierw w Niemczech, a potem w luterańskich miastach innych państw, m.in. w dużych miastach pruskich ${ }^{44}$. Instytucja ta przetrwała okres kontrre-

${ }^{40}$ Z. K r o p i dło w s k i, Organizacja dzieł miłosierdzia, s. 141-144, 147, 152-153; tenże, Formy opieki nad ubogimi, s. 26, 42-53, 55-56, 60-61.

${ }^{41}$ Z. K r o p i d ł o w s k i, Formy opieki nad ubogimi, s. 58-59; A. S z a r s z e w s k i, Sprawy szpitali i sierocińców w aktach prawnych Rady Miasta Gdańska XVI-XVIII w., Toruń 2006, s. 71.

${ }^{42}$ Z. K r o p i d ł o w s k i, Formy opieki nad ubogimi, s. 60.

43 Tamże, s. 7; B. Ge r e m e k, Litość i szubienica, s. 216; J. T. M a c i u s z k o, Miłosierdzie, s. 56.

${ }^{44}$ W. K ri e g s e i s e n, Ewangelicy warszawscy w epoce saskiej, „,Rocznik Warszawski”, 28, 1999, s. 24; Z. K r o p i d ł o w s k i, Samopomoc w korporacjach rzemié́lniczych Gdańska, Torunia i Elblaga (XIV-XVIII wiek), Gdańsk 1997, s. 133. 
formacji i funkcjonowała jeszcze w XVIII w. Dzięki niej w epoce saskiej pomocą zboru warszawskiego objętych było w stolicy 10 luteranów, głównie kalek i wdów, a oprócz tego wypłacano zasiłki jednorazowe. Z czasem „kasę chorych” $\mathrm{w}$ Warszawie przemianowano w Wydział Jałmużniczy Zarządu Zboru ${ }^{45}$.

Instytucja kas, jako form samopomocy, rozpowszechniona też była w korporacjach zawodowych miast Prus Królewskich. Chodzi o cechy, które tworzyły specjalistyczne kasy zapomogowe dla swoich członków, a zwłaszcza rodzin po zmarłych rzemieślnikach. Były to kasy pogrzebowe, kasy wdów, kasy chorych, kasy czeladnicze czy też wspomniane wyżej kasy ubogich i kasy po luterańskich pastorach i kaznodziejach ${ }^{46}$.

W Gdańsku do idei „kasy ubogich” nawiązywały Boże Skarbony, praktykowane od lat dwudziestych XVI w. przez całe następne dwa stulecia. Były to dawne skarbony odpustowe umieszczane w kościołach, do których wierni składali jałmużny na cele dobroczynne. Zasoby skarbon uzupełniały efekty zbiórek przeprowadzanych przed świątyniami w prywatnych domach, dochodzily do tego fundusze z zapisów testamentowych. Kontrolę nad skrzyniami sprawowało w imieniu miasta czterech przełożonych zarządców Bożych Skarbon ${ }^{47}$.

Specyfiką luterańskiej dobroczynności była wielość form poza szpitalnej opieki. Umieszczenie i pobyt w szpitalu traktowano jako konieczność ostateczną. W jak największym natomiast zakresie starano się pomagać potrzebującym w ich własnych domach. Chodziło o wsparcie materialne w ubóstwie, ale także o leczenie i pomoc medyczną w chorobie. Odbiorców takiej pomocy nazywano ubogimi domowymi lub komornikami $^{48}$. Kiedy sytuacja nie była zbyt poważna, dostarczano chorym domowym darmowe lekarstwa. Wysyłano też do nich chirurgów i lekarzy, którzy na koszt miasta prowadzili leczenie. Stosowano protestancką zasadę udzielania pomocy tylko swoim ubogim, a odsyłania

\footnotetext{
${ }^{45}$ W. K ri e g s e i s e n, Ewangelicy warszawscy, s. 24.

46 E. K i zi k. Zabezpieczenie finansowe wdów $w$ Gdańsku $w$ XVII-XVIII wieku, „Kwartalnik Historii Kultury Materialnej”, 58, 2010, nr 1, s. 90-99; T e n ż e, Śmierć $w$ mieście hanzeatyckim $w$ XVI-XVIII wieku. Studium z nowożytnej kultury funeralnej, Gdańsk 1998, s. 243-259; Z. K r o p i dło w s k i, Samopomoc, s. 147-178.

47 Z. K ro pidło w s i, Formy opieki nad ubogimi, s. 30-31, 39, 41-42, 58, 98; E. C i és l a k, Obraz społeczeństwa, s. 274; A. S z a r s z e w s k i, ,,Tablica jałmużnicza”, s. 86, 89-91.

${ }^{48} \mathrm{Z}$. K r o p i d ł o w s k i, Formy opieki nad ubogimi, s. 26-27.
} 
do miejsc zamieszkania obcych ${ }^{49}$. Oprócz opieki medycznej ubodzy chorzy „mieszkający kątem” otrzymywali za pośrednictwem tacowych okresowe zasiłki, zapomogi i dary w naturze w swoich izbach. Ważną formą wsparcia potrzebujących było dostarczanie im żywności ${ }^{50}$. Istotną rolę w akcjach niesienia pomocy odegrał założony w $1540 \mathrm{r}$. Urząd Zapasów, który gromadził nadwyżki zboża i żywności oraz regulował ich ceny, hamował drożyzny. Dzięki temu, przy nagłych niedoborach, zboże można było sprzedawać ubogim po niskich cenach ${ }^{51}$.

Społeczność luterańska troszczyła się o żony i sieroty po zmarłych pastorach. Z myślą o tych kobietach tworzono instytucję tzw. „roku wdowiego, czasu miłosierdzia, łaski”, która przez kilka miesięcy - nie dłużej niż rok - zapewniała owdowiałym kobietom wypłatę części dotychczasowych dochodów męża, ulgę w podatkach, przydział opału i gratisowe mieszkanie oraz zwolnienie z kościelnych opłat pogrzebowych. Z przywilejów tych korzystały również wdowy po nauczycielach $^{52}$. W „luterańskim” Gdańsku można było ponadto spotkać indywidualne formy zabezpieczenia przyszłych wdów. Bogatsi mężowie jeszcze za życia lub na mocy testamentu tworzyli oprocentowane lokaty czy indywidualne rachunki oszczędnościowe, które w oparciu o tzw. Kasę Funduszy Posiłkowych, służyły wdowom lub sierotom. Najefektywniejszy sposób niesienia pomocy wdowom po ministrach stanowiły kasy wdowie. W 1633 r. powstała kasa wdowia kaznodziejów luterańskich zatrudnionych w kościołach gdańskich, a w 33 lat później powołano w Gdańsku kasę zapomogową dla rodzin po zmarłych duchownych luterańskich z Żuław Gdańskich. Podobnie organizowali się duchowni w Elblągu, gdzie kasa wdów po luterańskich kaznodziejach powstała w $1738 \mathrm{r}^{53}$. Należy jeszcze wspomnieć o wydanym w 1570 r. przez biskupa sambijskiego nakazie zakładania przy każdej parafii domków, w których miałyby zamieszkać wdowy i sieroty po pastorach ${ }^{54}$.

49 Tamże, s. 97-99, 103, 153.

${ }^{50}$ Tamże, s. 53, 55, 157; T e n ż e, Organizacja dziet miłosierdzia, s. 151.

${ }^{51}$ Z. K r o pi dło w s ki, Formy opieki nad ubogimi, s. 62, 75. Zob. też: M. B og u c k a, Urzad Zapasów a konsumpcja Gdańska w pierwszej połowie XVII wieku, „Kwartalnik Historii Kultury Materialnej”, 18, 1970, nr 2, s. 255, 258.

${ }^{52}$ Cyt. za: E. K i z i k, Zabezpieczenie finansowe, s. 90.

${ }^{53}$ E. K i z i k, Zabezpieczenie finansowe, s. 91-93; T e n ż e, Śmierć, s. 255-256.

54 Wizytacja biskupa sambijskiego z 1570 roku, wyd. J. W i j a c z k a, Toruń 2005, s. X. 
Gdy chodzi o opiekę nad starymi, wysłużonymi i chorymi pastorami zborów luterańskich, istotna była uchwala synodu w Miłosławiu w 1607 r., zalecająca, by pastorowi zapewnić uczciwe uposażenie i wsparcie w razie choroby lub starości ${ }^{55}$.

System opieki społecznej i szpitalnictwa Gdańsku już od średniowiecza dorównywał poziomem europejskim wzorcom. Nowatorskie przedsięwzięcia w opiece zdrowotnej i społecznej wypracowane przez reformację zrealizowano tu co najmniej o ćwierć wieku wcześniej niż w innych polskich miastach o silnej pozycji luteranizmu ${ }^{56}$. Szybkie przejęcie w XVI w. europejskich rozwiązań organizacyjnych w opiece społecznej, medycznej i prewencyjnej stanowiło fenomen tego miasta ${ }^{57}$. Luterański kanon opiekuńczy emanował na inne miasta, Torun czy Elbląg. Zapewne niektóre formy opieki praktykowane w Gdańsku albo przynajmniej jej namiastki, znajdowały naśladownictwo w mniejszych skupiskach i zborach luterańskich; chodzi szczególnie o opiekę domową, zasiłki, karbony, czy omówione kasy zapomogowe i samopomocowe. Stolica Prus Królewskich stała się jednym z przykładów skutecznej realizacji postulatów municypalnej opieki społecznej, wysuwanych na początku XVI w., przez Marcina Lutra, Ludwika Vivesa, Erazma z Roterdamu czy Andrzeja Frycza Modrzewskiego ${ }^{58}$. Organizowało ją luterańskie miasto, w przeciwieństwie do katolików, u których to Kościół poprzez swoje ustawodawstwo inicjował i inspirował większość działań charytatywnych.

Drugim miastem Prus Królewskich, w którym przeprowadzenie reformy luterskiej dało szansę rozszerzenia wpływów miasta na opiekę był Toruń, zamieszkiwany w połowie przez ludność niemiecką ${ }^{59}$. Wystąpienia pospólstwa w 1523 r. przeciwko radzie zmusiły władze miejskie do organizowania w nowym duchu opieki nad ubogimi. Podobnie było w Gdańsku, Elblągu i Baraniewie ${ }^{60}$. Na ostateczny kształt ustrojowy

\footnotetext{
55 J. D w o r z a c z k o w a, Reformacja i kontrreformacja, s. 212-213.

${ }^{56}$ Z. K r o p i d ł o w s k i, Formy opieki nad ubogimi, s. 80-81, 94.

57 Tamże, s. 166; Z. P og dó r s k a - K law e, Od hospicjum do wspótczesnego szpitala, Wrocław 1981, s. 36.

${ }^{58}$ B. Ge r e m e k, Litość i szubienica, s. 213-232.

59 S. C a c k o w s k i, Terytorium, ludność, władze miejskie, [w:] Historia Torunia, red M. B i s k u p, t. 2, cz. 2, W czasach renesansu, reformacji $i$ wczesnego baroku (1548-1660), Toruń 1994, s. 21-22; T. Glem ma, Stosunki kościelne w Toruniu w XVI i XVII stuleciu, „Roczniki Towarzystwa Naukowego w Toruniu”, 42, 1934, s. 22-23, 58.

${ }^{60} \mathrm{~J}$. D w o r z a c z k o w a, Reformacja i kontreformacja, s. 55.
} 
miasta decydujący wpływ wywarła Reformatio Sigismundi z 1523 r., która uchwalała prawa regulujące funkcjonowanie różnych instytucji miejskich, w tym instytucji opieki ${ }^{61}$. Z uwagi na mocno luterańskie oblicze miasta, opieka społeczna, zwłaszcza szpitalna, zorganizowana była tak jak w ewangelickim Gdańsku ${ }^{62}$. W połowie XVII w. Toruń posiadał pięć szpitali: dom wdów, dom dla ubogich św. Pawła i Piotra, szpital Św. Jerzego, szpital Św. Wawrzyńca, szpital Św. Katarzyny. Ponadto funkcjonował tam lazaret dla zadżumionych ${ }^{63}$.

Od drugiej połowy XVII w. najważniejszy akt prawny normujący funkcjonowanie toruńskiego szpitalnictwa stanowił regulamin z 1665 r., którego wystawcami byli burmistrz Torunia oraz magistrat, sprawujący prawo patronatu nad szpitalami ${ }^{64}$. Według niego, na szczycie struktury zarządzania szpitalami stała rada miejska, która spośród swoich członków delegowała $\mathrm{z}$ reguły dwóch, nakładając na nich obowiązek opieki nad administracją szpitalną w mieście. Określano ich panami deputowanymi lub prowizorami. Dyrektorowi urzędu przełożonych szpitalnych podlegali vorsteherzy, czyli przełożeni poszczególnych szpitali ${ }^{65}$. W szpitalach występowali również tzw. starsi szpitalni czyli szpitalnicy, którym podlegał opłacany świecki personel pomocniczy. Toruńskie szpitale miały strukturę zhierarchizowaną i sformalizowaną, która regulowana była przez przepisy narzucane przez radę miejską ${ }^{66}$. Posiadał też Toruń typową dla luteranizmu

${ }^{61} \mathrm{G}$. M a z e k, Opieka nad sierotami jako instytucja społeczna $w$ Toruniu $w$ początkach XVII wieku, [w:] Charitas. Miłosierdzie i opieka społeczna..., s. 131. Zob. S. C a c k o w s k i, Terytorium, s. 24; Historia Torunia, t. 2, cz. I, U schytku średniowiecza i w początkach odrodzenia 1454-1548, red. M. B i s k u p, Toruń 1992, s. 144-161.

${ }^{62}$ B. D r z e w i e c k i, K. P ę k a c k a - F a l k o w s k a, O protestanckiej miłości bliźniego czyli toruńska Ordinanz des Vorsteher-Amts wegen des Haltungen von die Armut z 1665 roku, ,Zapiski Historyczne”, 77, 2012, z. 3, s. 54-55.

63 J. D y g d a ł a, Organizacja, skład i funkcjonowanie samorządu miejskiego, [w:] Historia Torunia, t. 2, cz. III, Między barokiem a oświeceniem, red. M. B i s k u p, Toruń 1996, s. 35.

64 B. Drzewiecki, K. P ęk a cka-Falkowska, O protestanckiej miłości, s. 53.

65 Tamże, s. 54; K. P ę k a c k a - F a 1 k o w s k a, Wielka epidemia chorób zakaźnych $w$ nowożytnym Toruniu. Wielka zaraza $w$ trakcie III wojny północnej jako fakt totalny, Torun 2012, s. 11, przypis 44 (praca doktorska, Biblioteka Uniwersytetu Mikołaja Kopernika w Toruniu).

66 B. Drzewi e cki, K. P ę ka cka-Falkow s ka, O protestanckiej miłości, s. 52,54 . 
ustawę anty żebraczą. Była nią uchwalona przez radę miejską w $1653 \mathrm{r}$. ordynacja dla ubogich ${ }^{67}$.

W Toruniu, tak jak w Gdańsku, praktykowano instytucję Bożych Skarbon $^{68}$, organizowano kolekty i kwesty, podobny był sposób zarządzania szpitalami, ustawodawstwo przeciw żebracze i troska o najmłodszych. Istniał też urząd wójtów ubogich (wójtów żebra(zych) ${ }^{69}$. Było to jednak miasto mniejsze i nie tak prężne gospodarczo jak Gdańsk, miało zatem nieco uboższą i mniej różnorodną ofertę działań opiekuńczych.

W Toruniu i tamtejszych szpitalach funkcjonowała też dobrze i nowocześnie zorganizowana służba medyczna ${ }^{70}$, która w pierwszym rzędzie zabezpieczała potrzeby lazaretu. Ze strony miasta opiekę nad osobami prywatnymi w ich domach, chorymi przebywającymi w szpitalach oraz nad biedotą uliczną sprawował balwierz ${ }^{71}$. W mieście działało też kilku chirurgów, którzy mieli się zajmować „ranami i chorobami ubogich". Na czas epidemii rada miejska wyznaczała spośród nich chirurgów dżumowych (morowych). Oprócz nich byli balwierze dżumowi ${ }^{72}$. Chirurdzy dżumowi istnieli również w sąsiednich miastach: Elblągu, Malborku, Grudziądzu, Gniewie, Tczewie, Chojnicach, Gdańsku. Najwyższą pozycję w hierarchii personelu medycznego zajmowali lekarze miejscy, nadzorujący pracę balwierzy i chirurgów ${ }^{73}$. W XVI-XVII w. w Toruniu było od 2 do 5 lekarzy, absolwentów uniwersytetów europejskich ${ }^{74}$. Liczną służbę i zaplecze medyczne zapewniał działający w mieście cech balwierzy (cyrulików) i chirurgów.

\footnotetext{
${ }^{67}$ K. P ę k a c k a - F a 1 k o w s k a, Wielka epidemia, s. 23, przypis 66.

${ }^{68}$ B. D r z e w i e c k i, K. Pękacka-Falkowska, O protestanckiej miłości, s. 66.

${ }^{69}$ Tamże, s. 5, przypis 17, s. 28, przypis 63.

${ }^{70} \mathrm{~S}$. S a 1 m o n o w i c z, Kultura umystowa Torunia $w$ dobie renesansu, reformacji i wczesnego baroku, [w:] Historia Torunia, red M. B i s k u p, t. 2, cz. 2, W czasach renesansu, reformacji i wczesnego baroku (1548-1660), Toruń 1994, s. 222-223.

${ }^{71} \mathrm{~K}$. P ę k a c k a - F a l k o w s k a, Wielka epidemia, s. 25-26, przypis 68, 71.

72 Tamże, s. 25, przypis 69, s. 28, przypis 74-75, s. 31, przypis 81; T a ż, Toruńska medycyna $i$ farmacja wobec powietrza morowego $w$ świetle niemieckojęzycznego starodruku medycznego z 1709 roku, „Klio. Czasopismo poświęcone dziejom Polski i powszechnym”, 11 2008, s. 53-88; taż, Profilaktyka przeciwdżumowa w nowożytnym Toruniu na przykładzie działań administracyjnych i leczenia, Toruń 2009, s. 69-76.

${ }^{73} \mathrm{~K}$. P ę k a c k a - F a 1 k o w s k a, Wielka epidemia, s. 25, przypis 69, s. 26, przypis 72, s. 29, przypis 79, 32, przypis 82 .

${ }^{74}$ S. S a 1 m o n o w i c z, Kultura umystowa, s. 223-224.
} 
W pierwszej dekadzie XVIII w. funkcjonowało ponadto w Toruniu siedem izb balwierskich ${ }^{75}$.

Toruń posiadał też Dom Pracy Przymusowej. Otwarty pod koniec wojny północnej pozostawał pod bezpośrednim zarządem władz miejskich, pełnił funkcję dobroczynną a zarazem produkcyjną ${ }^{76}$.

Wielkim osiągnięciem luterańskiej administracji Torunia było stworzenie oryginalnego systemu pomocy dzieciom, zwłaszcza sierotom. Opieka nad nimi została tam wkomponowana w ogólny system instytucji miejskich, na czele $\mathrm{z}$ radą. Ważną rolę pełnił urząd kwaterny, z kwatermistrzami poszczególnych dzielnic. Jego zadaniem było wyszukiwanie osób wymagających opieki, m.in. sierot, a następnie zapewnianie im odpowiedniego wsparcia. W kwestii sierot fundamentalne znaczenie posiadała wydana w 1605 r. przez burmistrza toruńskiego, kalwina Henryka Strobanda ordynacja Patrocinium Pupillorum, powołująca tzw. urząd sierocy ${ }^{77}$. Regulował on sytuację prawną i materialną osieroconych dzieci, dbał o ich edukacje i majątek pozostawiony przez rodziców ${ }^{78}$. Dzięki temu dotychczasowa opieka ze strony kuratorów rodzinnych została zastąpiona działaniami opiekuńczymi władz i instytucji miejskich ${ }^{79}$. Ustawa o opiece nad sierotami uwzględniała najnowsze wzory holenderskie $w$ tym względzie ${ }^{80}$.

W działaniach władz toruńskich zracjonalizowana i zbiurokratyzowana opieka była normowana przepisami, które nie uwzględniały spontanicznego miłosierdzia, a nakładały na wszystkich obywateli obowiązek opieki nad sierotami ${ }^{81}$. Opinię tą można odnieść do innych

${ }^{75} \mathrm{~K}$. P ę k a c k a - F a l k o w s k a, Wielka epidemia, s. 28-29, przypis 73, 78. Zob. S. S o k ó 1, Historia gdańskiego cechu chirurgów, Wrocław 1951; S. H e r b s t, Toruńskie cechy rzemieślnicze. Zarys przeszłości, Torun 1933.

${ }^{76} \mathrm{~J}$. D y g d a ł a, W cieniu gtębokich konfliktów wyznaniowych, [w:] Historia Torunia, t. 2, cz. III, Między barokiem a oświeceniem, red. M. B i s k u p, Toruń 1996, s. 176; J. W o j t o w i c z, Dzieje handlu, przemystu i rzemiosta, [w:] Historia Torunia, t. 2, cz. III, Między barokiem a oświeceniem, red. M. B i s k u p, Toruń 1996, s. 78-79.

${ }^{77}$ K. K o l e n d o - K o r c z a k, Propaganda reform burmistrza Henryka Strobanda $w$ dekoracji sali Rady z 1603 roku w Ratuszu Staromiejskim Torunia, ZH, 74, 2009, z. 3, s. 46-47; G. M a z e k, Opieka nad sierotami, s. 132; Szerzej na temat H. S t r o b a n d a, D. D y b a ś, Burmistrz reformator. Wokót programu reformatorskiego Henryka Strobanda, „Zapiski Historyczne”, 66, 2001, z. 4, s. 51-64.

${ }^{78}$ K. K o l e n d o - K o r c z a k, Propaganda reform, s. 46-47.

${ }^{79}$ G. M a z e k, Opieka nad sierotami, s. 132.

${ }^{80} \mathrm{~S} . \mathrm{C}$ a c k o w s k i, Terytorium, s. 28.

${ }^{81}$ G. M a z e k, Opieka nad sierotami, s. 137. 
inicjatyw podejmowanych przez luterańskie władze miejskie względem pozostałych potrzebujących w miastach, w których protestanci augsburscy stanowili większość i sprawowali władzę.

Pewne symptomy opieki praktykowanej przez reformację luterańską występowały w Poznaniu. W 1633 r. tamtejsza rada miejska wydała walkę żebractwu. Dla zaopatrzenia zaś naprawdę potrzebujących umieściła w kościele parafialnym św. Marii Magdaleny skarbony na jałmużnę ${ }^{82}$. Na przełomie XVI i XVII w. w Poznaniu istniały dwa zbory ewangelicko - augsburskie. Przy jednym z nich istniał w $1601 \mathrm{r}$. „luterski szpital, gdzie ubóstwo mieszkało"83.

Własne placówki charytatywne posiadali ewangelicy augsburscy jeszcze w kilku innych enklawach wielkomiejskich. Jedną z nich w połowie XVII w. stanowili warszawscy luteranie, którzy w 1650 r. otrzymali zgodę na powołanie przy parafii ewangelicko-reformowanej szpitala ${ }^{84}$. Dopiero jednak pod koniec epoki saskiej udało się luteranom wybudować w Warszawie szpital, który służył ewangelikom augsburskim i reformowanym $^{85}$. Na przełomie XVI i XVII w. swój szpital mieli także protestanci (zapewne luteranie) w Bydgoszczy. Protestanci, tworzacy w Bydgoszczy skonsolidowane grupy, rozsiane wśród społeczeństwa katolickiego, wzajemnie się wspomagali, otaczając swych ubogich dużą troską ${ }^{86}$.

Niewiele wiadomo o szpitalu luterańskim w Wilnie, z wyjątkiem tego, że na pewno tam istniał wraz z innym szpitalem ewangelików reformowanych ${ }^{87}$. Generalnie luteranie w Wielkim Księstwie Litewskim

${ }^{82} \mathrm{~J}$. D w o r z a c z k o w a, Reformacja i kontrreformacja, s. 65-66.

83 J. Łuk a s z e w i c z, Wiadomości historyczne o dysydentach $w$ Poznaniu $w$ XVI i XVII wieku, Poznań 1832, s. 142-144. 167, 197.

${ }^{84}$ W. Krie g s e is e n, Ewangelicy warszawscy, s. 16-17; L. O t t o, Przyczynek do historii zboru ewangelicko-augsburskiego warszawskiego 1650-1781, Warszawa 1881; L. W a c h h o 1 z, Szpitale krakowskie 1220-1920, t. 1, Kraków 1921, s. 37.

${ }^{85}$ W. K r i e g s e i s e n, Miłosierdzie, s. 118-119; Tenże, Ewangelicy warszawscy, s. 28; Z. P o d g ó r s k a - K l a w e, Szpitale warszawskie 1388-1945, Warszawa 1975, s. 66. ${ }^{86} \mathrm{~W}$. K. K or pals k a, Szpitale $w$ Bydgoszczy do końca XVIII wieku, „Archiwum Historii i Filozofii medycyny, 62, 1999, z. 4, s. 397-398 (383-399); T a ż, Sześć wieków opieki zdrowotnej w Bydgoszczy, Toruń 2008, s. 61. Szpital ten zwany heretycki istniał już w 1596. D. C h yła, Opieka społeczna na Kujawach w latach 1577-1792, Lublin 2015, s. 70-73.

${ }^{87}$ J. M a r o s z e k, Wileńskie przytułki - szpitale w XVI-XVIII wieku, [w:] Cała historia to dzieje ludzi... studia z historii społecznej ofiarowane prof. Andrzejowi Wyczańskiemu $w$ 80. rocznice urodzin i 55-lecie pracy naukowej, red. C. K u k l a, Białystok 2004, s. 192; T. K ę p a, Luteranie w wielkim Księstwie Litewskim, [w:] Kościół lute- 
byli środowiskiem słabym liczebnie. Nie posiadali, tak jak kalwini, wyraźnych liderów i bogatych protektorów, którzy mogliby mocniej przyczynić się do fundowania szpitali. Na Litwie swój szpital mieli jeszcze luteranie w Gocieniszkach ${ }^{88}$. Sprzyjające warunki do rozwoju szpitali na Litwie i innych terenach Rzeczypospolitej uzyskali luteranie dopiero w czasach tuż przedrozbiorowych, gdy w 1768 r. sejm zatwierdził traktat, zwany warszawskim, gwarantujący prawosławnym i protestantom pełną wolność kultu i posiadania szpitali ${ }^{89}$.

Na terenie Krakowa luteranie współdziałający z kalwinami posiadali wspólny zbór ${ }^{90}$. Być może wspólnym celom obu wyznań służył szpital zbudowany przez kalwinów w końcu trzeciej ćwierci XVI w. w Brogu przy ulicy św. Jana ${ }^{91}$.

Opieki społecznej organizowanej w środowiskach ewangelików augsburskich nie można rozpatrywać bez nawiązania do pietyzmu, ruchu religijno-mistycznego w luteranizmie niemieckim. Pietyzm, którego twórca był teolog luterański Filip Jakub Spencer (1635-1705) kładł nacisk $\mathrm{m}$. in. na ożywienie wiary, religijność indywidualną, wysokie wymagania moralne. Do ugruntowania swoich idei pietyści wykorzystywali także instytucję szkoły, nieobojętna im też była działalność charytatywna $^{92}$. W tej dziedzinie szczególne znaczenie miała dokonania pietysty Augusta Hermana Franckego (1663-1727), który zorganizował w Halle wiele zakładów wychowawczo-szkolnych dla biednych dzieci, sierocińców, a także rozwijał inne inicjatywy pomocowe ${ }^{93}$. Uważał, że cały obszar życia publicznego i socjalnego, w tym opieka, powinny być oparte na zasadach Ewangelii i przykazaniu miłości bliźniego, dlatego umacniał wśród społeczeństwa świadomość chrześcijańskiej odpowiedzialności

rański na ziemiach polskich (XVI-XX w.) w czasach Rzeczypospolitej Obojga Narodów, red. J. Kł a c z k o w, Toruń 2012, s, 105, 118.

${ }^{88}$ T. K ę p a, Luteranie, s. 89, 117; D. F r i e c k, ,Libellus chamorum”. Protestancka elita mieszczańska a szlachta $w$ Wilnie $w$ XVII wieku, [w:] Litwa $w$ epoce Wazów, red. W. K r i e g s e i s e n, Warszawa 2006, s. 242.

${ }^{89}$ T. K ę p a, Luteranie, s. 143.

${ }^{90}$ M. K o s m a n, Protestanci, s. 94.

${ }^{91} \mathrm{~L}$. W a c h h o l z, Z dziejów zboru ewangelickiego $w$ Krakowie, „Reformacja w Polsce", 1, 1921, nr 4, s. 268-270; T e nż e, O szpitalach, s. 174-175; S. T w or e k, Działalność oświatowo-kulturalna kalwinizmu małopolskiego, Lublin 1970, s. 112.

92 S. Li t a k, Historia wychowania do wielkiej rewolucji francuskiej, Kraków 2004, s. 194. Zob. też: S. S a 1 m o n o w i c z, Życie luteranów, s. 125.

${ }^{93}$ S. L i t a k, Historia wychowania, 194; E. B y r t e k, Mitosierdzie, s. 71-72. 
za bliźniego. Stworzył też zawód diakonisy, kobiety zajmującej się pracą charytatywno-opiekuńczą, to dzięki niemu pietyści zaczęli propagować ideę służby i pomocy dla potrzebujących - diakonii i związanej z nią działalności diakonalnej ${ }^{94}$. Pietyzm przeniknął na ziemie polskie stosunkowo szybko. Najbardziej jednak zakorzenił się w Cieszynie, głównym ośrodku tego ruchu ${ }^{95}$. W rękach sympatyków pietyzmu znalazła się powstała około 1712 r. w tym mieście szkoła ewangelicka, będąca swego rodzaju alumnatem, w którym biedniejsi uczniowie otrzymywali za darmo naukę, utrzymanie i wikt ${ }^{96}$. Było to możliwe dzięki szczodrobliwości tamtejszego ludu, któremu pietyści zaszczepili „radość ze składania ofiar", manifestowaną w zapisach testamentowych na rzecz szpitali, szkół i kościołów ${ }^{97}$. Myśl pietystyczna dotarła też do innych skupisk ewangelików reformowanych na terenach Rzeczypospolitej, chociażby do Torunia $^{98}$. Odcisnęła też swoje piętno w Lesznie, w którym ewangelicy prowadzili: szpital, szkołę z wyżywieniem dla ubogich dzieci, organizowali stałe zapomogi dla wdów i sierot, fundowali stypendia uczniom i studentom. Prawdopodobnie pietyści przyczynili się też do powstania w 1736 r. szpitala ewangelickiego w Warszawie i zwiększonej aktywności hojności luteranów na cele dobroczynne ${ }^{99}$.

W kościele luterańskim na polu opieki społecznej aktywne były również kobiety - protestantki, które dotowały zbory i szpitale. Zapisy na szpitale miejskie czyniły luteranki poznańskie. Jedna z nich uposażyła w 1613 r. cztery miejscowe przytułki, inna wsparła w 1684 r. zakłady: św. Walentego, św. Krzyża i Lazaret ${ }^{100}$. Zgodnie z anty żebraczą i antyjałmużniczą doktryną swego wyznania, nie miały też (także ich mężowie), motywacji do świadczenia spontanicznego miłosierdzia, jak miało to miejsce w katolicyzmie.

Formy miejskiej i świeckiej opieki społecznej wypracowane w społecznościach luterańskich stały się tworem stałym, a w dużych miastach,

\footnotetext{
${ }^{94}$ E. B y r t e k, Miłosierdzie, s. 73-74.

95 A. G i e row s k i, Pietyzm na ziemiach polskich (do połowy XVIII wieku), „Śląski Kwartalnik Historyczny Sobótka”, 27, 1972, nr 2, s. 247, 258.

${ }^{96}$ E. B y r t e k, Miłosierdzie, s. 76.

97 Tamże, s. 76; B. P o 1 o c z k o w a, Fundacje społeczne mieszkańców Cieszyna XVXX w., „Pamiętnik Cieszyński”, 6, 1993, s. 26.

${ }^{98}$ S. S a 1 m o n o w i c z, Życie luteranów, s. 125.

${ }^{99}$ E. B y r t e k, Miłosierdzie, s. 77.

100 A. K a r p iń s k i, Kobieta $w$ mieście polskim $w$ drugiej połowie XVI $i$ wVII wieku, Warszawa 1996, s 241, 276-277.
} 
jak Gdańsk i wielu mniejszych, przetrwały postępujący na ziemiach polskich proces kontrreformacji. Stworzone np. w Toruniu rozwiązania z początku XVI w., a wśród nich ordynacja opiekuńcza, nie uległy zasadniczym zmianom aż do momentu włączenia tego miasta do Prus $^{101}$. Stanowiły istotne osiągniecie i fundament, na którym owe miasta w pozaborowych czasach mogły budować dziewiętnastowieczny system opieki społecznej, modyfikując wcześniejsze protestanckie rozwiązania $^{102}$.

Reasumując można powiedzieć, że luteranie polscy, a zwłaszcza największe ich skupiska miejskie skutecznie wcieliły w życie municypalną reformę opieki społecznej lansowaną w XVI w. na Zachodzie Europy głównie w środowiskach protestanckich, i to zarówno ewangelików augsburskich, jak i kalwińskich. W naszym kraju recepcja tejże reformy nastąpiła tylko w miastach „luterańskich”, bowiem kalwinizm posiadał tu przede wszystkim oblicze agrarno-wiejskie. W warunkach miast polskich nie była to jednak opieka zcentralizowana, tak jak w Europie, gdzie często spotkać się można było z interwencją władz państwowych czy królewskich $w$ te sprawy ${ }^{103}$. Na gruncie polskim problem ten regulowały wyłącznie władze municypalne, przy znaczącym udziale ludzi świeckich ${ }^{104}$. W wypadku ewangelików augsburskich można mówić o racjonalnym, zaplanowanym przez miasto systemie działań opiekuńczych zmierzających do całościowego uregulowania problemu ubóstwa i żebractwa w oparciu nie tylko o szpitale, ale także poprzez rozwiązania administracyjne, uwzględniające nawet konieczność użycia siły i przymusowego zamknięcia.

Luterańska koncepcja miłosierdzia oparta była na etosie pracy i krytyce lenistwa. Opieka i dzieła charytatywne nie wynikały z dobrowolnych gestów i pobożności, ale wchodziły w zakres powinności społecznej, w skutek czego następowała ze strony władz miejskich ich instytucjonalizacja i profesjonalizacja. Dotychczasową, spontaniczną i przypadkową dobroczynność inspirowaną przez Kościół skutecznie zastąpiły działania wyspecjalizowanych, świeckich służb publicznych ${ }^{105}$.

\footnotetext{
101 G. M a z e k, Opieka nad sierotami, s. 138.

102 O. B a r t e 1, Marcin Luter w Polsce, „Odrodzenie i Reformacja w Polsce”, 7, 1962, s. 41-42.

${ }^{103}$ Por. B. Ge r e m e k, Litość i szubienica, s. 177.

104 Zob. J. T. M a c i u s z k o, Miłosierdzie, s. 54.

105 Tamże, s. 55-56.
} 


\section{Kalwinizm}

W przeciwieństwie do zdominowanej przez luteranizm Wielkopolski i Pomorza Gdańskiego, nauka Kalwina największe sukcesy odnotowała w środowiskach szlacheckich Małopolski i Wielkiego Księstwa Litewskiego. Trzecia prowincja kościoła kalwińskiego w Wielkopolsce, w porównaniu z prowincją małopolską i wileńską, była już zdecydowanie słabsza ${ }^{106}$. Kalwinizm odpowiadał szlachcie dzięki demokratycznej strukturze organizacji kościelnej ${ }^{107}$. $Z$ tego też względu szlachta kalwińska była w swoim kościele oraz podległych sobie dobrach głównym inicjatorem opieki społecznej. Choć posiadała ona własną specyfikę, to jednak jej formy były bardziej podobne do działań charytatywnych w kościele katolickim niż w kościele ewangelików augsburskich. Wynikało to $\mathrm{z}$ polskiego $\mathrm{w}$ większości oblicza reformacji kalwińskiej, dla której rodzime, katolickie wzorce opieki były bliższe od w dużym stopniu niemieckich rozwiązań luterańskich.

Opieka nad potrzebującymi w kalwinizmie polskim, podobnie jak i u katolików prowadzona była przede wszystkim w oparciu o szpitale. Szpitalna dobroczynność $w$ jednocie kalwińskiej nie miała jednak wymiaru tak dominującego i równoważona była inicjatywami poza instytucjonalnymi. Posiadała specyfikę mniej religijną, a więcej świecką, była bardziej samorządowa, a nawet demokratyczna. Swego rodzaju laickość opieki u ewangelików reformowanych powodował też brak bractw, szczególnie zakonów, które w obozie kontreformacyjnym dały pewną możliwość specjalizacji szpitali (sierocińce szarytek) czy wykreowały typ większego szpitala-lecznicy (bonifratrzy). W konsekwencji szpitale kalwińskie były mniejsze i przybierały jeszcze bardziej funkcję przytułku.

Podobnie jak i w Kościele katolickim, również w Jednocie ewangelicko-reformowanej to na parafiach spoczywał obowiązek wypełniania funkcji edukacyjnych i opiekuńczych. Przeto każdy zbór miał posiadać nie tylko świątynię, ale także szkołę i szpital ${ }^{108}$. Genezą fundacji

\footnotetext{
106 Por. H. G mite re k, Bracia czescy a kalwini w Rzeczypospolitej. Połowa XVIpołowa XVII wieku, Lublin 1987, s. 12-13, T e n ż e, Włodawa w dziejach reformacji i kultury staropolskiej, [w:] Dzieje Włodawy, red. R. S z c z y g i e ł, E. O l s z e w s k i, Włodawa 1991, s. 57.

${ }^{107}$ K. Le p s z y, A. K a m iń s k a, Geneza i program, s. 54; M. K o s m a n, Protestanci, s. 19, 21.

${ }^{108}$ W. Kri e g s e i s e n, Miłosierdzie, s. 116-117.
} 
szpitali kalwińskich i ariańskich była decyzja właścicieli dóbr, w których były zakładane ${ }^{109}$.

Sieć przytułków kalwińskich można odtworzyć jedynie dla terenu Wielkiego Księstwa Litewskiego, i to przede wszystkim dla XVIII w., a więc schyłkowego okresu reformacji ${ }^{110}$. Najstarsza informacja o ewangelickiej fundacji szpitalnej na Litwie przy zborze w Bielicy pochodzi z 1559 r. W 1598 r. szpital ewangelicko-reformowany ufundowany został w Wilnie. Kolejne zborowe przytułki na terenie Wielkiego Księstwa powstały w: Zabłudowie na Podlasiu (1621 lub 1608), Słucku (przed 1627), Sidrze (przed 1630), Nurcu (1631) ${ }^{111}$. Do najstarszych należał szpital kalwiński w Wisielubiu, w 1621 r. określany jako „dawny"112. Wszystkie zostały utworzone z inicjatywy rodzin szlachecko-magnackich, szczególnie potężnych Radziwiłów, protektorów kalwinizmu litewskiego. Troskę o ubogich w swoich dobrach wykazywał Krzysztof Radziwiłł (syn „Pioruna”), według którego takie placówki powinny istnieć przy wszystkich zborach. W 1621 r. polecił swemu administratorowi, by zadbał o wybudowanie szpitali przy ośmiu zborach, zaś w Nowym Mieście nakazał utrzymywać ,parę ubogich... dla pilnowania zboru i dzwonienia, gdy minister przyjedzie"113

Szczególnie aktywna była Ludwika Karolina z Radziwiłłów, która zapisami z 1687 i 1693 r. zabezpieczyła byt domu opieki w Słucku, Bielicy i Zabłudowie, ale także kilku innych wcześniej założonych szpitali, w: Orli, Węgrowie na Podlasiu, Kopylu, Kojdanowie (w XVI w.?), Lubeczu, Sielcu i Dokudowie w Wielkim Księstwie Litewskim. Wszystkie znajdowały się w jej prywatnych dobrach, zwanych później „neuburskimi”"114. Przytułek zborowy posiadali ewangelicy w miejsco-

${ }^{109}$ Z. G ó r a l s k i, Szpitale na Lubelszczyźnie w okresie przedrozbiorowym w okresie przedrozbiorowym, Warszawa-Łódź 1982, s. 32.

110 W. K ri e g s e i s e n, Miłosierdzie, s. 116.

111 Tamże, s. 117-119.

112 Akta synodów prowincjonalnych Jednoty Litewskiej 1611-1625, Monumenta Reformationis Poloniae et Lituaniae, Seria IV, Zeszyt II, Wilno 1915, s. XXII.

113 Tamże, s. XVII-XXIV. Szpitale miały powstać w zborach: Birże, Popiel, Wiżajny, Bielica, Zabłudów, Lubecz, Dokudowo, Lipnicza. Nie wiadomo, ile tych szpitali faktycznie powstało (na pewno w Birży i Zabłudowie).

114 E. B a g i ń s k a, Działalność religijna Radziwiłtów birżańskich $w$ dobrach podlaskich w XVII wieku, „Studia Podlaskie', 12, 2002, s. 208, 213; W. P a r t y k a, Opieka społeczna w Ordynacji Zamojskiej w XVII-XVIII wieku, Lublin 2008, s. 20; J. M a ros ze k, Dzieje zboru kalwińskiego w Zabłudowie w latach 1608-1868, [w:] Mój 
wości Szwabiska (przed 1766) oraz w diecezji żmudzkiej w Szydłowie i Greżach. Rozwój szpitali kalwińskich wspierali nie tylko magnaccy wyznawcy tej konfesji - jednym z nich był koniuszy litewski Franciszek Stefan Sapieha, który w latach osiemdziesiątych XVII w. fundował lub wspierał finansowo szpitale w Boćkach i Lachowiczach ${ }^{115}$.

Pomimo sukcesywnego słabnięcia społeczności ewangelickiej najważniejsze parafie Jednoty Litewskiej utrzymały swe domy opieki do końca Rzeczypospolitej szlacheckiej. Jeszcze w 1801 r. w czterech litewskich dystryktach (diecezjach) Kościoła kalwińskiego, na 24 parafie ewangelicko-reformowane było 10 szpitali (w Birżach, Kiejdanach, Kielmach, Kopysi, Żupranach, Bielicy, Kojdanowie, Kopylu, Słucku i Wilnie $)^{116}$. W schyłkowej fazie istnienia państwa polskiego kalwini litewscy dysponowali więc stosunkowo gęstą siecią szpitali (ok. 42\% zborów z taką placówką), porównywalną nawet do sieci katolików ${ }^{117}$. W sumie Jednota Litewska posiadała przynajmniej 20 szpitali, działających w różnych fazach doby przedrozbiorowej. Być może jest to liczba niepełna, co jednak nie oznacza, że w końcu XVI i na początku XVII stulecia, w czasach rozkwitu reformacji, współczynnik parafii kalwińskich ze szpitalami był wyższy, ponieważ kilkakrotnie więcej było wtedy zborów ewangelickich ${ }^{118}$. Warto zauważyć, że z wyjątkiem Wilna, Słucka, szpitale zborowe działały w małych miasteczkach, a nawet wsiach (Szwabiska, Lubecz, Nurzec). Dwa szpitale innowiercze - kalwiński i luterański - istniały w prężnym ośrodku refor-

Kościót $w$ historię wpisany. Księga pamiątkowa dedykowana Księdzu Profesorowi Tadeuszowi Krahelowi, red. T. K a s a b u $\nmid$ a, A. S z o t, Białystok 2007, s. 283-284, 290, 294; Akta synodów prowincjonalnych Jednoty Litewskiej 1611-1625, s. 28, 83.

115 B. G r y k o, Sapieżyńskie fundacje szpitali jako przejaw miłosierdzia?, „Białostockie Teki Historyczne”, 8, 2010, s. 56. Przytułek w Szydłowie istniał już przed 1627 r. Zob. Akta synodów prowincjonalnych Jednoty Litewskiej 1626-1637, opr. M. L i e d k e, P. G u z o w s k i, Warszawa 2011, s. 25.

116 W. Krie g s e i s e n, Miłosierdzie, s. 119, 124, 127; M. K o s m a n, Litewska Jednota, s. 40. Ten drugi autor podaje w 1768 r. 38 parafii kalwińskich na Litwie.

117 M. S u r d a c ki, Sieć szpitali łacińskich w Rzeczypospolitej w XVI-XVIII wieku, „Nasza Przeszłość”, 123, 2015, s. 133-184.

118 W. Krie g s e i s e n, Ewangelicy polscy i litewscy w epoce saskiej (1696-1763), Warszawa 1996, s 100-101; H. Merczyng, Zbory i senatorowie protestanccy w dawnej Rzeczypospolitej, Warszawa 1904, s. 16-17. Zob. też: M. K o s m a n, Sytuacja prawno-polityczna kalwinizmu litewskiego $w$ drugiej połowie XVII wieku, „Odrodzenie i Reformacja w Polsce”, 20, 1975, s. 84-85; T e n ż e, Litewska Jednota, s. $6-7,39,40$. 
macyjnym, w podległym biskupom warmińskim Królewcu. Wzmianki o nich pochodzą z 1668 r. $^{119}$.

Szpitale ewangelicko-reformowane można było spotkać na innych terenach Rzeczypospolitej. W Krakowie gmina reformowana, po uzyskaniu w 1569 r. zgody Zygmunta Augusta, wybudowała szpital dla swoich ubogich wyznawców w Brogu przy ulicy św. Jana. Był on trzykrotnie niszczony przez studentów w czasie antyinnowierczych tumultów. Po ostatniej profanacji Brogu, zbór ewangelicki wraz ze szpitalem przeniesiono najpierw do Aleksandrowic, potem do wsi Wielkinocy, w której istniał do 1775 r. $^{120}$. W Warszawie skromny drewniany przytułek protestanci założyli w 1736 r. przy cmentarzu ewangelickim na Lesznie, który służył chorym i podróżnym ewangelikom wyznania augsburskiego, jak i mniej licznego - reformowanego $^{121}$. W 5 lat później na terenie cmentarza stanął drugi 8 - izbowy szpital służący obu zborom ${ }^{122}$. W 1777 r. ewangelicy reformowani przystąpili do prac nad organizowaniem własnego szpitala ${ }^{123}$.

Na terenie Korony, podobnie jak na Litwie, szpitale ewangelickoreformowane zakładano nade wszystko w małych, prywatnych miastach szlachty kalwińskiej. Sporo ich powstało jeszcze w drugiej połowie XVI stulecia zwłaszcza w województwie lubelskim - w: Babinie, Bełżycach, Piaskach, Radzyniu, Siedlcach ${ }^{124}$, Kocku (był w 1637) ${ }^{125}$. Szpital ewangelików reformowanych istniał prawdopodobnie w samym

119 U. A u g u s t y n i a k, Testamenty ewangelików reformowanych $w$ Wielkim Księstwie Litewskim, Warszawa 1992, s. 206.

${ }^{120}$ L. W a c h h o lz, Z dziejów zboru, s. 268-270; T e n ż e, O szpitalach, s. 174-175; S. T w o r e k, Działalność, s. 112.

121 W. Kri e g s e is e n, Miłosierdzie, s. 118-119; T e nż e, Ewangelicy polscy, s 28; Z. Podgórska-Klawe, Szpitale warszawskie, s. 66; E. B y rte k, Miłosierdzie, s. 77.

${ }^{122}$ Z. P o d g ó r s k a - K l a w e, Szpitale warszawskie, s. 66; L. S p i e s s, Opis szpitala ewangelickiego $w$ Warszawie, [w:] Rys historyczno-statystyczny szpitali $i$ innych zaktadów dobroczynnych w Królestwie Polskim, t. 2, Warszawa 1872, s. 37-39; K. N e u g e b a u e r, Rys historyczny Szpitala Ewangelickiego w Warszawie, Warszawa 1931, s. 8.

${ }^{123}$ W. Kri e g s e i s e n, Miłosierdzie, s. 119.

124 Z. Gó r a l s k i, Szpitale na Lubelszczyźnie, s. 27; W. K r i e g s e i s e n, Miłosierdzie, s. 118; K. B e m, Zbór w Piaskach koło Lublina, „Odrodzenie i Reformacja w Polsce", 43, 1999, s. 81. Góralski wymienia też szpital kalwiński w Urzędowie, co nie jest prawdą. Zob. M. S u rd a c k i, Urzędów w XVII - XVIII wieku. MiastoSpołeczeństwo-Życie codzienne, Lublin 2007, s. 55-60.

125 S. T w o r e k, Działalność, s. 255. 
Lublinie $^{126}$. Najdłużej, do 1727 r., przetrwał szpital bełżycki ${ }^{127}$. Krócej funkcjonował przytułek innowierczy w Piaskach, który według relacji z 1713 r. zupełnie się zapadł ${ }^{128}$. Pozostałe przytułki kończyły swój żywot dużo wcześniej wraz z ze słabnięciem reformacji i upadkiem zborów, przy których istniały ${ }^{129}$. Zapewne już w 1627 r. nie posiadali domu opieki ewangelicy w Lublinie, którzy w skutek tumultu w tym roku przenieśli swój zbór do pobliskich Piasków ${ }^{130}$. Na terenie Małopolski istniał też szpital kalwiński w Baranowie (zniesiony w 1652) ${ }^{131}$, a ponadto szpital w Olkuszu ${ }^{132}$.

Oprócz wyżej wymienionych szpitale kalwińskie istniały w wielu innych, zwłaszcza większych zborach i ośrodkach Jednoty augsburskiej. Podczas synodu we Wodzisławiu w 1566 r., uchwalono, że hospitalia seu ptochodochia dla ubogich i pielgrzymów winny znajdować się w każdej parafii ewangelików reformowanych, natomiast, w 1608 r. synod w Lublinie polecił utworzyć przytułek dla lubelskiej wspólnoty ewangelickiej $^{133}$. O tym, że szpitale kalwińskie w prowincji małopolskiej nie były zjawiskiem wyjątkowym świadczy fakt, że wspominano o nich podczas dysput synodalnych w 1606, 1622, 1626 r. $^{134}$.

Istnienie szpitali kalwińskich $\mathrm{w}$ prowincji wielkopolskiej potwierdzają zapisy i legaty na cele charytatywne - głównie na szpitale,

126 Akta synodów różnowierczych w Polsce (1550-1559), opr. M. S i p a yłł o, t. 3, Warszawa 1983, s. 360; A. K o s s o w s k i, Protestantyzm w Lublinie $i$ w Lubelskiem w XVI-XVII wieku, Lublin 1933, s. 147.

${ }^{127}$ W. Kri e g s e i s e n, Ewangelicy polscy, s. 211.

${ }^{128}$ K. B e m, Zbór w Piaskach, s. 96.

129 Z. G ó r a 1 s k i, Szpitale na Lubelszczyźnie, s. 27.

130 J. Łuka s z e wi c z, Dzieje Kościołów wyznania helweckiego $w$ dawnej Małej Polsce, Poznań 1853, s. 366-371.

${ }^{131}$ S. T w o r e k, Działalność, s. 294.

132 D. M o le n d a, Opieka zdrowotna i społeczna górników olkuskich $w$ XV-XVIII wieku, [w:] Szpitalnictwo $w$ dawnej Polsce, red. M. D ą b row s k a, J. K r u p pé, Warszawa 1998, s. 64; T a ż, Dzieje Olkusza do 1795 r., [w:] Dzieje Olkusza i regionu olkuskiego, red. F. K i r y k, R. K o ł o d z i e j c z y k, Warszawa 1978, t. 1, s. 255-256; J. W y rozu mski, Początki opieki społecznej w górnictwie polskim, [w:] Prace z dziejów Polski feudalnej, ofiarowane Romanowi Grodeckiemu w 70 rocznicę urodzin, Warszawa 1960, s. 221; F. G i e d r o y ć, Zapiski do dziejów szpitalnictwa w dawnej Polsce, Warszawa 1908, s. 43.

133 Akta synodów różnowierczych $w$ Polsce (1560-1570), opr. M. S i p a yłło, t. 2, Warszawa 1972, s. 206; Akta synodów różnowierczych, t. 3, s. 288.

${ }^{134}$ Akta synodów różnowierczych, t. 3, s. 278, 439, 490. 
oraz edukacyjne - na stypendia dla uczniów i studentów ${ }^{135}$. Szpital kalwiński, usytuowany za Bramą Rydzyńską, funkcjonował w 1778 r. w Lesznie ${ }^{136}$. Taką samą placówkę posiadali kalwini w Poznaniu. Podczas rozruchów antyinnowierczych w 1614 r. została ona spalona, ,a ubogie żebraki w szpitalu będące, potłuczono, poraniono i ze wszystkiego, co mieli, obrano"137.

O wpisanie na listę stałych „beneficjentów” i umieszczeniu w szpitalu zborowym decydowały świeckie władze Kościoła w porozumieniu z superintendentami dystryktowymi nadzorującymi szpitale parafialne $^{138}$. Z wyjątkiem szpitali litewskich, niewiele informacji posiadamy o ich pensjonariuszach. W szpitalu kalwińskim w Kiejdanach, zamieszkiwanym w 1679 r. przez 9 osób, było pięcioro ewangelików i czworo katolików ${ }^{139}$. Świadczy to o przełamywaniu obowiązujących wtedy stereotypów o wyłącznie konfesyjnym charakterze instytucji charytatywnych, a także o tolerancyjnej postawie ewangelików, a praktycznie kalwińskich patronów i protektorów zboru kiejdanowskiego. Zdarzało się nawet, że w drugiej ćwierci XVII w. kalwini litewscy przekazywali jałmużny najmocniej ich zwalczającym jezuitom. Inną postawę wykazywali katolicy w Słucku, którzy około połowy XVIII w. w czasie grabieży zboru próbowali wypędzić kalwinów z ich domu szpitalnego i umieścić swoich poddanych ${ }^{140}$.

Przytułki kalwińskie miały drewnianą konstrukcją ${ }^{141}$, a liczbą pensjonariuszy przypominały katolickie szpitale parafialne ${ }^{142}$. Były niewielkie, gdyż same zbory stanowiły małe wspólnoty, liczące często

135 W. K ri e g s e is e n, Ewangelicy polscy, s. 134.

${ }^{136}$ Drugi szpital protestancki - wyznania luterańskiego - położony był przed Bramą Rydzyńską. AAP, AV 33, Visitatio generalis archidiconatus Śremensis, s. 209.

137 Akta synodów różnowierczych $w$ Polsce (1569-1632), opr. M. S i p a yłł o, t .4, Warszawa 1997, s. 39. Szpital w Poznaniu istniał na pewno w 1587 r., s. 98.

138 W. Kri e g s e i s e n, Miłosierdzie, s. 121-122; M. K o s m a n, Litewska Jednota, s. 8; U. A u gustyniak, Dwór i klientela Krzysztofa Radziwilta 91585-1640). Mechanizmy patronatu, Warszawa 2001, s. 46.

139 S. T w o r e k, Materiały do dziejów kalwinizmu w Wielkim Księstwie Litewskim w XVII wieku, „Odrodzenie i Reformacja w Polsce”, 14,1969, s. 207, 215.

${ }^{140}$ M. K o s m a n, Litewska Jednota, s. 20, 44.

${ }^{141}$ W. Kri e g s e i s e n, Miłosierdzie, s. 119-121.

${ }^{142}$ Cztery szpitale, które w 1621 r. nakazał wybudować K. Radziwiłł miały być przeznaczone dla sześciu osób, pozostałe dla ośmiu, dziesięciu i dwunastu. Akta synodów prowincjonalnych Jednoty Litewskiej 1611-1625, s. XVIII-XXIII. 
około kilkadziesiąt osób lub co najwyżej rodzin ${ }^{143}$. Zbory ponad stuosobowe występowały wyłącznie w największych miastach Rzeczypospolitej, w Wilnie, Lublinie czy Krakowie ${ }^{144}$.

Niektóre szpitale ewangelickie były jednak dobrze urządzone. Szpital w Nurcu w pierwszej połowie XVII w. składał się z dwu budynków. Jeden przeznaczony był dla ubogich wyższej kondycji, drugi dla pospolitych żebraków. W tym samym czasie przytułek w Sidrze utrzymywać mógł sześciu ubogich zborowych ${ }^{145}$. Z kolei w drewnianym, dwuizbowym szpitalu w Kojdanowie przebywały w latach 1728-1733 trzy osoby. W 1746 r. w przytułku kojdanowskim znajdowały się dwie „babki szpitalne” - obie szlachcianki, które otrzymywały dodatkowo rocznie po 60 zł. zapomogi. W 1794 był tam już inny, ośmioizbowy budynek szpitalny, gwarantujący opiekę liczniejszym pensjonariuszom. Dobrze urządzony szpital funkcjonował w Słucku. W 1685 r. posiadał skromny domek dla szpitalników oraz duży, wygodny i wieloizbowy szpital dla „lepszej” klienteli, konkretnie dla wdów ewangeliczek. W XVIII w. oba przytułki zlikwidowano, a osoby pozostające na utrzymaniu wspólnoty, mieszkały w udostępnionych przez parafię reformowaną domach prywatnych. Trzy kobiety z rodzin szlacheckich zamieszkiwały w 1720 r. domu opieki w Żupanach. Trzydzieści lat później przyjęto do niego staruszkę, która wspomagano dodatkowo sumą 60 zł rocznego zasiłku. Również w Birżach tzw. „dom sierocy” służył jako przytułek dla wdów, które po zniszczeniu budynku w 1757 r. przeniesiono do szkoły ${ }^{146}$.

Z powyższych informacji wynika, że oprócz osób biednych, pozbawionych środków do życia, dużą część pensjonariuszy litewskich szpitali ewangelicko-reformowanych stanowiły osoby zamożne w większości kobiety, z reguły wdowy ze środowisk szlacheckich, niekiedy kalekie. Takie nobilitowane ,panny” z różnymi ułomnościami korzystały w XVIII w. z opieki zboru wileńskiego czy z pomocy finansowej władz dystryktu zawilejskiego (birżańskiego) ${ }^{147}$.

\footnotetext{
${ }^{143}$ K. B e m, Zbór w Piaskach, s. 81; W. Kriegseisen, Ewangelicy polscy, s. 119.

${ }^{144}$ R. Ż e le w s k i, Zaburzenia wyznaniowe w Krakowie. Okres przewagi różnowierców 1551-1573, „Odrodzenie i Reformacja w Polsce”, 6, 1961, s. 106.

145 W. Kri e g s e i s e n, Miłosierdzie, s. 117.

146 Tamże, s. 120-121, 124, 125.

147 Tamże, s. 122-123.
} 
Szpitale ewangelików helweckich na ziem litewskich zaspakajały w pierwszym rzędzie potrzeby własnego środowiska, a więc tego które je organizowało. Ich opieka posiadała charakter elitarny; skierowana była na wsparcie osób nie koniecznie najbiedniejszych, lecz pochodzących ze zubożałych kręgów szlacheckich. Była to więc samopomoc szlachty kalwińskiej. Chłopi i poddani w mniejszym stopniu korzystali z opieki w istniejących na terenie Wielkiego Księstwa Litewskiego szpitalach ewangelickich ${ }^{148}$.

Opieka nad szpitalami kalwińskimi spoczywała w gestii ministrów poszczególnych zborów, teoretycznie podlegających synodowi, który ich wybierał. W praktyce ministrowie zależni byli we wszystkim od patrona danego miejsca ${ }^{149}$. Duchownych ministrów wspomagali seniorzy świeccy, ustanawiani na synodach dla każdego dystryktu. Mieli oni między innymi troszczyć się o biednych, o publiczne szkoły, nauczycieli i szpitale ${ }^{150}$. Przykładowo dla zboru lubelskiego na synodzie w 1608 r. wybrano ich czterech, po dwóch Niemców i Szkotów, co potwierdza obcy skład narodowościowy zborów kalwińskich w większych miastach ${ }^{151}$. Mieli się oni zatroszczyć o wybudowanie szpitala zborowego i decydować o kryteriach przyjmowania do niego pensjonariuszy. Przechowywali też skrzynkę zborową i dysponowali jej zasobami, szafowali pieniędzmi na ubogich ${ }^{152}$. Szpitalami kalwińskimi zarządzali bezpośrednio szafarze (dozorcy) ${ }^{153}$.

\footnotetext{
148 Por. tamże, s. $117,127$.

149 S. T w o r e k, Działalność, s. 44-45; O opiece ministrów nad szpitalami dyskutowano na synodach w 1558, 1560 i 1658 r. Zob. Akta synodów różnowierczych w Polsce (1550-1559), opr. M. S i p a yłł o, t. 1, Warszawa 1966, s. 279; Akta synodów różnowierczych, t. 2, s. 41, 206.

${ }^{150} \mathrm{~S}$. T w o r e k, Z zagadnień organizacji zborów kalwińskich $w$ Małopolsce $w$ XVIXVII wieku, „Rocznik Lubelski”, 8, 1965, s. 65-66; Akta synodów różnowierczych, t. 1, s. 306; J. K a c zor, Protestantyzm $w$ powiecie radomskim $w$ XVI-XVIII wieku, [w:] Radom i region radomski w dobie szlacheckiej Rzeczypospolitej, red. Z. G u 1 d o n, S. Z i e l i ń s k i, Radom 1996, s. 133.

151 Akta synodów różnowierczych, t. 3, s. 288; A. K o s s o w s k i, Protestantyzm w Lublinie, s. 18; J. Łu k a s z e w i c z, Dzieje Kościołów wyznania helweckiego, s. 367, 341; S. T w o r e k, Z zagadnień ruchu kalwińskiego w Małopolsce, „Rocznik Lubelski", 10, 1967, 153.

152 Akta synodów różnowierczych, t. 3, s. 288, 295.

${ }^{153} \mathrm{Z}$ reguły był jeden taki administrator, nieraz dwóch. Akta synodów prowincjonalnych Jednoty Litewskiej 1611-1625, s. X, 4-6, 26. 48.
} 
Ważną rolę w zborach w dziedzinie dobroczynności ogrywali diakoni. Wybierani na synodach dystryktowych, mieli występować we wszystkich kościołach i parafiach ewangelicko-reformowanych, niezależnie od tego czy działały przy nich szpitale ${ }^{154}$. Według uchwał synodu z 1559 r., ich powinnością było zbieranie do skrzynek jałmużny, która cztery razy $\mathrm{w}$ roku miała być w połowie przeznaczona na utrzymanie ubogich ${ }^{155}$. Według postanowień synodów w Lublinie z 1601 i 1608 r. ich zadaniem było stać po nabożeństwie „z misą u drzwi zborowych”, trzymać skrzynkę zborową i puszkę ubogich. W czasie jarmarków mogli też kwestować w gospodach. Liczba diakonów zależała od potrzeb zboru. W Wilnie na początku XVII w. było ich trzech ${ }^{156}$. W 1608 r. ustanowiono dla zboru lubelskiego czterech diakonów narodowości szkockiej i niemieckiej. Gdy w mieście pojawił się szpital ewangelicki, kolejny synod z 1615 r. nakazał diakonom troską o niego ${ }^{157}$. Instytucja skrzynki czy karbony zborowej, nazywanej też mons pietatis (monte pietatis), była charakterystyczną cechą dobroczynności w Jednocie helweckiej, opartej w głównej mierze na solidarności wspólnotowej. Według uchwał synodu generalnego w Książu z 1560 r. zbiórki takie, przeznaczone również na cele ogólno kościelne, miały być organizowane dwa razy w roku, a do szczodrobliwości wezwani byli wszyscy członkowie Jednoty, łącznie z ministrami ${ }^{158}$

Ważną kategorią podopiecznych, którymi opiekowano się w Kościele ewangelików reformowanych były sieroty. Liczba diakonów zależała od potrzeb zboru. W Wilnie na początku XVII w. było ich trzech ${ }^{159}$. Niektóre $\mathrm{z}$ nich znajdowały schronienie $\mathrm{w}$ przytułkach, np. w 1737 r. w szpitalu birżańskim mieszkało troje osieroconych dzieci. W trosce o sieroty szlachcianka Rachela Rychlicka legowała w 1724 r. 1000 florenów na dom sierocy przy zborze żuprańskim. Specyfiką kalwińskiej opieki społecznej było zapewnianie wdowom i sierotom nie tylko dachu nad głową w przytułkach zborowych, ale także przydzielanie wsparcia finansowego ${ }^{160}$.

\footnotetext{
${ }^{154}$ Akta synodów różnowierczych, t. 3, s. 342, 418; Akta synodów różnowierczych, t. 2, s. 61.

155 Akta synodów różnowierczych, t. 1, s. 306.

${ }^{156}$ Akta synodów prowincjonalnych Jednoty Litewskiej 1611-1625, s. 35, 44, 53.

157 Akta synodów różnowierczych, t. 3, s. 225, 289, 360.

158 Akta synodów różnowierczych, t. 2, s. 59.

159 Akta synodów prowincjonalnych Jednoty Litewskiej 1611-1625, s. 35, 44, 53

${ }^{160}$ W. K ri e g s e i s e n, Miłosierdzie, s. 123-124.
} 
Ważną uchwałę „o wdowach i dziatkach mistrzowskich” podjęto podczas synodu generalnego w Wilnie w 1621 r. Zakazano mianowicie, by po śmierci ministra, jego żona i dzieci nie były natychmiast rugowane z plebani, aż do momentu znalezienia sobie nowego domostwa ${ }^{161}$.

Największą troskę społeczność ewangelików reformowanych wykazywała o dzieci, a także wdowy po zmarłych ministrach zborowych. Akta synodów w kościele ewangelicko-reformowanym, pełne są uchwał i apeli kierowanych do swych wyznawców o pomoc dla sierot po zborowych ministrach ${ }^{162}$. W 1623 r. na prośbę synodu dystryktowego w Lublinie jeden z jego uczestników wziął pod protekcję i pieczę sieroty nieboszczyka księdza Jezierskiego ${ }^{163}$.

Na mocy zjazdu prowincjonalnego ministrów z 1566 r. we Włodzisławiu, główną opiekę nad rodziną zmarłego powierzono czterem ministrom wybranym spośród pastorów zborowych, którzy pełnili rolę patronów wdów i sierot, a zarazem zarządców należącego do nich majątku. Ich obowiązkiem było godne pochowanie zmarłego, następnie zinwentaryzowanie pozostałych po nim ruchomości i sprzętów. Rzeczy prywatne miała otrzymać małżonka i jej dzieci. Gdy wdowa była biedna, mieli jej przydzielić na gruntach kościelnych domek z ogrodem, w którym mogła dokonać dożywocia. Ponadto ministrowie ci zobowiązani byli czuwać nad wychowaniem osieroconych dzieci aż do ich dorosłości; chłopcom mieli doradzać wybór zawodu i studiów, zaś dziewczęta przygotowywać do zarządzania gospodarstwem i uczyć pobożności oraz wyposażyć wianem. Niezależnie od czterech opiekunów, to ministrów poszczególnych zborów zobowiązano do pilnowania i pomnażania majątku sierot po swoich poprzednikach ${ }^{164}$.

Inaczej rozwiązano sprawę wdowy po księdzu na konwokacji dystryktowej w Ożarowie w 1622 r., podczas której pozostały inwentarz żywy i nieruchomy podzielono między dwóch dorosłych synów, zaś kobiecie, przy której zostały młodsze dzieci wyznaczono trzech opiekunów, w tym jednego księdza. Pragnąc zabezpieczyć przyszłe losy

\footnotetext{
161 Akta synodów prowincjonalnych Jednoty Litewskiej 1611-1625, s. 62-63.

162 Synod w Poznaniu (1579) oraz w Gołuchowie (1597 i 1600). Akta synodów różnowierczych, t. 4, s. 62, 129, 364.

163 Akta synodów różnowierczych, t. 3, s. 447. O konieczności wyznaczania opiekunów dla wszystkich sierot wspominano na synodzie w Koźminku w 1602 r. oraz w czasie wizytacji w 1612 r. Akta synodów różnowierczych, t. 4, s. 175, 251.

${ }^{164}$ Akta synodów różnowierczych, t. 2. 207-208.
} 
dzieci na wypadek śmierci ojców-kapłanów i zapobiec nadużyciom związanym z pozostawionym majątkiem, zalecono w 1612 r. na synodzie w Lublinie, a potem $\mathrm{w}$ tym samym roku na zjeździe prowincjonalnym w Ożarowie, by ministrowie jeszcze za życia spisywali testamenty. Gdyby jednak zmarli nie uczyniwszy tego, duchowni seniorzy zobowiązani byli wybrać opiekunów, którzy mieli spisać inwentarz rzeczy po ministrze, a następnie przedyskutować z władzami sprawę opieki nad dziećmi i żoną ${ }^{165}$.

Kolegialnie i demokratyczne kierowana Jednota kalwińska, dbała o to, aby wszelkie długi należne zmarłym ministrom były szybko rewindykowane na rzecz ich osieroconych dzieci ${ }^{166}$. Aby ułatwić i skoordynować pomoc ministerialnym sierotom na synodzie partykularnym $\mathrm{w}$ obradującym lubelskim grodzie w 1619 r. postanowiono spisać regestr dzieci osieroconych przez ewangelickich duchownych ${ }^{167}$. Na Litwie problem sierot po zasłużonych dla Kościoła osobach najczęściej rozwiązywano poprzez wyznaczanie im „beneficjów”, np. synod w Bielicy z 1730 r. nakazał wypłacenie zasiłku na wnuczkę pobożnego kolatora zborowego ${ }^{168}$. Problem opieki nad dziećmi i żonami po zmarłych ministrach rozpatrywano też szczegółowo na innych synodach $(1605,1620)^{169}$.

Społeczność kalwińska nie zapominała przede wszystkim o zubożałych, wysłużonych, starych, schorowanych ministrach. Niekiedy kapłani osobiście zwracali się o pomoc do władz synodu. W 1614 r. ksiądz Piotr Milicius pisał do uczestników synodu w Biłgoraju: „abyście bracia o mnie radzili i mnie subsidium jakowe obmyślili”. O poratowanie w starości poprosił też w 1602 r. „w leciech zeszły” ksiądz Wojciech Episcopius. Często sami zebrani na synodzie wychodzili z ofertą pomocy. Obradujący na zjeździe w Okszy w 1605 r. postanowili zakupić ze składek wysłużonemu księdzu domek mieszkalny. Innym razem na konwokacji w 1624 r., Walerian Otwinowski dobrowolnie przyjął do siebie na utrzymanie niezdolnego do dalszej pracy pastora, któremu wspólnota zobowiązała się wypłacać roczną kontrybucję. Władze synodalne zwracały się (1622) też bezpośrednio do patrona zboru o zwolnienie chorego kapłana z funkcji i odpowiednie

\footnotetext{
165 Akta synodów różnowierczych, t. 3, s. 325, 336, 435.

166 Synody z lat (1616-1622). Tamże, s. 386, 397, 409, 416, 427, 437.

167 Akta synodów różnowierczych, t. 3, s. 408.

${ }^{168}$ W. K ri e g s e i s e n, Miłosierdzie, s. 123.

${ }^{169}$ Akta synodów różnowierczych, t. 3, s. 191, 270, 418.
} 
jego opatrzenie finansowe. $\mathrm{Z}$ innych ciekawszych przypadków wspierania ministrów warto wymienić: przekazanie 10 złotych księdzu kalwińskiemu uchodzącemu z Węgier (1605), apel do patronów i seniorów zborowych o pomoc dla złożonego chorobą księdza Marcina Janiciusa, który przetłumaczył Biblię (1604). W rezultacie otrzymał 40 florenów na żywność z kolekty oraz 50 florenów rocznie od starosty lwowskiego ,na wychowanie" ${ }^{\text {,170 }}$.

Ponadto pomocą Kościół helwecki otaczał osoby uznawane za szczególnie zasłużone dla Jednoty. Do takich zaliczali się zubożali patronowie zborów, jak np. pani Trzeciakowa, której w 1704 r. wypłacono 250 złotych, a następnie odesłano pod opiekę podkomorzyny dreptskiej. Oryginalną formą pomocy spotykaną na ziemiach litewskich, było udzielanie zgody na bezpłatne wzniesienie na terenie zborowym budynku mieszkalnego. $Z$ takich możliwości korzystali ludzie starzy, ale i zamożne wdowy, np. w 1702 r. dwie wdowy, jedna po patronie zboru, druga po duchownym osiadły się przy kościele ewangelickim w Dokudowie oraz w Kojdanowie. W 1791 r. w Słucku na gruncie kościelnym zamieszkiwało aż pięć rezydentek, w tym trzy siostry ${ }^{171}$.

Oprócz osób z elit szlacheckich i bogatego mieszczaństwa starych i chorych ministrów oraz pozostałych po nich wdów i sierot ${ }^{172}$ Kościół ewangelicko-reformowany pomagał innym wyznawcom kalwinizmu potrzebującym pomocy $\mathrm{z}$ niższych warstw społecznych. O ile nie znajdowali schronienia w szpitalach, byli oni zdani na łaskę i hojność bogatszych współbraci. N synodzie lubelskim w 1601 r. nakazano sporządzanie regestrów ubogich, a ministrom polecono uświadamiać $\mathrm{w}$ czasie kazań istniejące $\mathrm{w}$ tym zakresie potrzeby. Zbieraniem jałmużny dla ubogich zajmowali się diakoni. Do przeprowadzania kolekt na ratowanie ubogich nawoływano na synodach w Ożarowie w 1621 i 1626 r. $^{173}$. Trafiały się też prywatne, jednorazowe datki, np. podczas w synodu w Okszy w 1622 r., kiedy mąż z żoną darowali ,na ubóstwo" 54 florenów. Na wsparcie najbiedniejszych przeznaczano kary finansowe za przewinienia i naruszenie powinności wspólnotowych, np. za niestawianie się na synodach ${ }^{174}$.

\footnotetext{
170 Tamże, s. 236, 263, 270-271, 351, 439, 456.

${ }^{171}$ W. Kri e g s e i s e n, Miłosierdzie, s. 125-126.

172 W. Kri e g s e i s e n, Ewangelicy polscy, s. 121.

${ }^{173}$ Akta synodów różnowierczych, t. 3, s. 225, 288-289, 432, 488.

174 Tamże, s. 188; W. K r i e g s e i s e n, Miłosierdzie, s. 127.
} 
Władze Jednoty nie pozostawały obojętne na potrzeby ubogich uczniów i studentów, fundując im stypendia. Wspólnota litewska pokrywała w połowie XVIII w. wydatki na koszta podroży i zasiłki dla studentów przejeżdżających przez Królewiec. Z kolei w rachunkach Jednoty Małopolskiej z drugiej ćwierci XVIII w. stałą pozycją były wydatki na zasiłki dla alumnów, tj. studentów teologii ${ }^{175}$.

Podstawową formą utrzymania zborów przez wyznawców były dobrowolne składki-kolekty. W 1575 r. w zborze krakowskim obowiązywały np. trzy rodzaje kolekt. Pierwsza z nich, ogólna przeznaczona była na kupienie pałacu i budowę szpitala, druga kwartalna na utrzymanie i wychowanie ministrów, trzecia na katechistów, lektorów i diakonów ${ }^{176}$. Kolekty, w tym na działalność opiekuńczą, zarządzano na synodach, np. w Włodzisławiu w 1558 r. ${ }^{177}$.

Kolekty były również najpopularniejszym sposobem gromadzenia funduszy na pomoc sierotom po zmarłych ministrach, a także na wsparcie schorowanych i starych ministrów. Na mocy synodu generalnego we Włodzisławiu w 1566 r. nakazano zbierać jałmużny dla sierot. Podczas obrad synodalnych zebrano na ten cel od 21 ministrów poszczególnych zborów 88 florenów ${ }^{178}$.

Efekty kolekt zalecano przedkładać na forum synodu, który rozdysponowywał pieniądze między osierocone przez ministrów dzieci z wszystkich kościołów. W 1627 r. na konwokacji dystryktowej w Kocku przywiezione 150 florenów rozdzielono na potrzeby sierot, pięciu wdów", na drogę starszym" jadącym na synod włodawski oraz dla alumna i dwóch diakonów ${ }^{179}$. Również na synodach w Bełżycach odbytych w 1634 i 1637 r. pieniądze z kolekt dystryktu lubelskiego postanowiono przeznaczać na wdowy i sieroty po zmarłych ministrach ${ }^{180}$.

Dramatyczna sytuacja zaistniała w latach dwudziestych XVII w. we wspólnocie ewangelików lubelskich na wskutek dokonanego tumultu. W tej sytuacji kolejne synody w Kocku w 1625 i 1627 r., a później w 1630 r. w Biłgoraju, przekazały 50 florenów na jałmużnę

\footnotetext{
175 W. Kri e g s e i s e n, Ewangelicy polscy, s. 125, 134, 147.

176 Tamże, s. 55-56.

177 Akta synodów różnowierczych, t. 1, s. 274; S. T w o r e k, Działalność, s. 55. (autor ten niedokładnie podał dane liczbowe).

${ }^{178}$ Akta synodów różnowierczych, t. 2, s. 208.

179 Akta synodów różnowierczych, t. 3, s. 247, 269, 282, 339.

${ }^{180}$ A. K o s s o w s k i, Protestantyzm w Lublinie, s. 166.
} 
„złupionym i poburzonym ofiarom”, a następnie wydały zalecenie, by do momentu odrestaurowania zboru lubelskiego, na pomoc jego potrzebującym, zwłaszcza sierotom, zorganizować kolekty w innych wspólnotach ewangelickich regionu ${ }^{181}$.

Przeprowadzano też kolekty na potrzeby innych Kościołów ewangelickich. Gdy na bazie uchodźców z Czech i Śląska zakładano nową gmin wyznaniową we Włodawie synody kalwińskie z lat 1631 i 1633 ogłosiły na jej rzecz specjalne kolekty po zborach ${ }^{182}$. W 1708 r. synod litewski w Kiejdanach zarządził zbiórkę na odbudowę Leszna, zrabowanego i spalonego przez wojska rosyjskie ${ }^{183}$. Czasami z pomoca na poratowanie zborów przychodzili indywidualni dobroczyńcy. Wojewoda wileński Mikołaj Czarny Radziwiłł, przekazał na synodzie generalnym w 1560 r. w Książu 1600 talarów na szkołę i utrzymanie ubogich w mieście ${ }^{184}$.

Dochody małopolskich i litewskich ewangelików reformowanych z kolekt krajowych uzupełniane były efektami zbiórek zagranicznych. Największe ich nasilenie przypadło na drugą połowę XVII w. Pieniądze zbierano wśród współwyznawców: w Anglii, Irlandii, Niemczech, Niderlandach, a także w Prusach Książęcych, Inflantach, Kurlandii. Zebrane sumy przeznaczano na ogólne potrzeby kościoła kalwińskiego w Rzeczypospolitej, w tym na cele dobroczynne czy zapomogowe. Zdarzały się też inne rezultaty zagranicznych kolekt. Zbierający pieniądze w latach 1717-1718 w Anglii i Niemczech na zlecenie Jednoty Litewskiej ks. Bogusław Kopijewicz, oprócz zgromadzenia kwoty 65000 złotych, uzyskał też dwa stałe stypendia dla kalwińskich studentów teologii na Uniwersytecie w Edynburgu ${ }^{185}$.

Poważnym źródłem finansowania zborów, w tym także opiekuńczej działalności Kościoła, były fundacje i ofiary ze strony jego wyznawców. Wysokość ofiarowanych sum w Jednocie litewskiej na cele charytatywne była bardzo różna, od $50 \mathrm{zł}$. ofiarowanych w 1712 r.

\footnotetext{
181 Akta synodów różnowierczych, t. 3, s. 466, 492, 539.

182 Tamże, s. 559; A. K o s s o w s k i, Protestantyzm w Lublinie, s. 166; H. G m i t e r e k, Włodawa $w$ dziejach, s. 60; J. Łu k a s z e w i c z, Dzieje Kościołów wyznania helweckiego, s. 428.

${ }^{183}$ W. K ri e g s e i s e n, Ewangelicy polscy, s. 137.

${ }^{184}$ Akta synodów różnowierczych, t. 2, s. 53; S. T w o r e k, Działalność, 56.

185 W. Kri e g s e i s e n, Ewangelicy polscy, s. 137-143; Zob. też: M. K o s m a n, Litewska Jednota, s. 46.
} 
na szpital zboru wileńskiego do 1000 talarów zapisanych w 1702 r. na szpitale zborowe w Szydłowie i Greżach. Z terenu Wielkiego Księstwa Litewskiego znanych jest 19 poważniejszych donacji dobroczynnych, dokonanych w pierwszej połowie XVIII w. W większości były to fundacje szlacheckie, rzadziej mieszczańskie ${ }^{186}$.

Fundacje dobroczynne znane były w całym Kościele kalwińskim. Mieli je również stanowiący zdecydowaną mniejszość wśród luteranów, kalwini gdańscy. Z ofiarowanych kapitałów dawali dostateczne wsparcie ludziom starym, wdowom i sierotom ze swej wspólnoty. Niejednokrotnie z ich pomocy korzystali nawet biedni z sąsiednich miejscowości ${ }^{187}$.

Istotne wsparcie finansowe, przeznaczane na działalność charytatywną stanowiły zapisy testamentowe szlachty kalwińskiej, zwłaszcza Radziwiłłów. Czasami były to wysokie sumy, zabezpieczające funkcjonowanie szpitali na wiele lat. Na mocy testamentu z 1668 r. koniuszego wielkiego litewskiego Bogusława Radziwiłła, aż 2000 zł. otrzymały szpitale królewieckie, po połowie kalwiński i luterański. Również 2000 zł. legował on na trzy inne szpitale: słucki, wileński i kiejdański, zaś kolejne 1000 zł. przeznaczył na szpitale ruskie i pozostałe ewangelickie. W 1667 r. Anna Maria Radziwiłłowa ofiarowała na szpitale ewangelickie 1000 zł. i taką samą sumę na „oprawę” zboru oraz potrzeby ubogich i kaznodziejów. Zapisów testamentowych dokonali ponadto Krzysztof Mikołaj Dorohostajewski w 1615 r. na szpital w Wilnie oraz Katarzyna Grabowska z Oborskich w 1729 r. na szpital w Kojdanowie. Z kolei wojewodzina wileńska Katarzyna z Radziwiłłów Hlebowiczowa zapisała w 1674 r. 1000 zł. na ubogie, sieroty i wdowy zborowe, a oprócz tego kolejne sumy dla sług i czeladzi ${ }^{188}$.

Hojnością testamentową kalwińscy panowie wyrażali podwładnym sługom i klientom wdzięczność za dotychczasową służbę i pomnażanie ich majątku, zabezpieczając $w$ ten sposób ich byt na starośćc ${ }^{189}$. W testamencie z 1620 kasztelan wileński Janusz Radziwiłł polecił, by słudzy, którzy wiernie mu służyli, dostali „,na odprawę, na pogrze-

\footnotetext{
186 W. Kri e g s e i s e n, Miłosierdzie, s. 123, 127.

187 Z. K r o p i d ło w s k i, Formy opieki nad ubogimi, s. 165.

${ }^{188}$ U. A u g u s t y n i a k, Testamenty ewangelików, s. 135, 191, 206, 217, 232, 220.

189 U. A u g u s t y n i a k, ,Stary stuga” jako przedmiot badań nad klientelizmem magnackim na Litwie w XVII wieku, „Kwartalnik Historii Kultury Materialnej”, 58, 2010, nr 1, s. 77.
} 
bowe albo insze potrzeby"190. Szlachta litewska, zwłaszcza Radziwiłłowie birżańscy jako patronowie zborów i wielkich włości spełniali wobec podopiecznych sług $\mathrm{i}$ ich rodzin (sierot i wdów) wszechstronne funkcje opieki socjalnej, dostarczając im wsparcia materialnego jak i opieki lekarskiej. Przykładem takiego opiekuna i protektora był Krzysztof Radziwiłł, syn swego imiennika „Pioruna”. Niewątpliwie postawie opiekuńczej Radziwiłłów, patronów generalnych Jednoty litewskiej, sprzyjała świadomość wspólnoty wyznaniowej ${ }^{191}$.

Podstawą funkcjonowania Kościoła ewangelicko-reformowanego był budżet generalny, z którego poszczególne prowincje prowadziły skomplikowaną gospodarkę finansową. Rozdysponowywany był on na różne cele przez władze centralne na zjazdach synodalnych. W Jednocie Litewskiej część dochodów z budżetu przeznaczano na działalność charytatywną. Przykładowo z budżetu 1728/1729 r. wypłacono 120 złotych na „ubogą szlachtę szydłowską” oraz 455 złotych pro subsidio charitativo dla cześnika bełskiego Stankara ${ }^{192}$.

Oceniając opiekę społeczną w Jednocie ewangelicko-reformowanej, można stwierdzić, że nie odbiegała ona poziomem od opieki organizowanej przez Kościół katolicki i jego wiernych. Jednakże jej bardzo liczne i różnorodne formy były nieco inne, w mniejszym stopniu oparte o system szpitalny, a bardziej zwrócone na pomoc materialno-finansową potrzebującym bez konieczności umieszczania ich w przytułkach. Akcje opiekuńcze, wychodzące od wewnątrz samej wspólnoty kierowane kolegialnie za pośrednictwem synodów obejmowały w pierwszym rzędzie osoby bezpośrednio związane z funkcjonowaniem gmin wyznaniowych, to jest patronów ministrów oraz ich rodziny; dopiero dalszej kolejności i w mniejszym stopniu zaspakajały potrzeby najuboższych współwyznawców. W ogólnym bilansie działań charytatywnych, dominującą formę wsparcia stanowiły wszelkiego rodzaju zapomogi, zasiłki, subsydia, subwencje oparte na świadczeniach wiernych (kolekty, karbony), a także na zapisach czy fundacjach możnych ofiarodawców i testatorów. Mniej w rozwiązaniach kalwińskich było miejsca na klasyczne miłosierdzie i przygodną jałmużnę, zbieraną przez żebraków

\footnotetext{
${ }^{190}$ U. A u g u s t y n i a k, Testamenty ewangelików, s. 174.

${ }^{191}$ U. A u g u s t y n i a k, Dwór i klientela, s. 185-186, 188-189; T a ż, „Stary stuga”, s. 78-79, 81-82.

${ }^{192}$ W. Kri e g s e i s e n, Ewangelicy polscy, s. 126; M. K o s m a n, Litewska Jednota, s. 12.
} 
i włóczęgów. Tych ostatnich zresztą wśród wyznawców kalwinizmu nie było zbyt wielu, ponieważ w większości odbiorcami pomocy była szlachta, bądź jej poddani, którzy przywiązani do folwarków, nie byli tak mobilni jak biedota wielkomiejska. Poza tym mniejszość kalwińska, zabiegając o nowych zwolenników, musiała być dla nich atrakcyjna również w sprawach opiekuńczo - socjalnych, zmuszona była oferować korzystne, a nawet lepsze niż w katolicyzmie perspektywy na wypadek choroby, starości czy ubóstwa.

Szukając analogi, system opieki społecznej u ewangelików reformowanych najbardziej zbliżony był do wypracowanego w bratnim Kościele braci czeskich, pod względem struktury społecznej, bardzo podobnym do kalwińskiego. Zresztą obydwie te grupy konfesyjne pozostawały od początku w ścisłych kontaktach i zależnościach, a z czasem nastąpił niejako proces roztapiania się Jednoty Czeskiej w kalwinizmie. We Włodawie na przykład zbór kalwiński powstał na bazie osiedlonej w 1628 r. grupki uchodźców czeskich ${ }^{193}$. Środowisko ewangelików helweckich pobawione też było możliwości leczenia szpitalnego chorych, co w mniejszym czy większym stopniu miało jednak miejsce u katolików, a zwłaszcza luteranów. Chorzy mogli co najwyżej korzystać z pomocy lekarzy dochodzących.

Pomimo że opieka u ewangelików reformowanych posiadała własne, uniwersalne oblicze, to jednak między dwiema największymi prowincjami Rzeczypospolitej można było zauważyć w tym zakresie pewne różnice, uwarunkowane strukturą majątkową szlachty kalwińskiej i pozycją kościoła ewangelicko-reformowanego, zdecydowanie najmocniejszego na Litwie ${ }^{194}$. Lepiej zorganizowana była na terenach litewskich, gdzie większe znaczenie miały względnie liczne i dobrze uposażone szpitale. Więcej tam było dużych fundacji i zapisów na cele dobroczynne ze strony potężnego gospodarczo i politycznie rodu Radziwiłłów, którzy nie szczędzili środków na zakładanie szpitali i inną nie instytucjonalną pomoc dla swych mniej zamożnych współwyznawców. Jak ważna była przychylna postawa bogatych patronów świadczy przywilej z 1650 r. wydany przez Bogusława Radziwiłła dla cudzoziemców wyznania ewangelickiego: genewskiego i augsbur-

${ }^{193}$ H. G m i t e r e k, Bracia czescy a kalwini, s. 6; tenże, Włodawa w dziejach, s. 60-61. Zob. też: M. W a j s b l u m, O wyznaniowym obliczu, s. 89.

${ }^{194}$ Por. M. K o s m a n, Litewska Jednota, s. 6, 10. 
skiego chcących osiedlić się w Węgrowie, w którym obiecał wszelkie swobody i wolności a także pomoc przy zakładaniu szkół i szpitali. W 1662 r. podobny przywilej otrzymali cudzoziemcy nacji szkockiej w Zabłudowie ${ }^{195}$. Małopolska natomiast tak wielkich protektorów nie miała, toteż i szpitale kalwińskie były w niej zjawiskiem rzadszym, a legaty na cele charytatywne drobniejszej szlachty mniej okazałe. Opieka w małopolskim Kościele reformowanym bardziej bazowała na ofiarności szeregowych członków wspólnoty.

Mimo wszystko nie sprzyjała rozwojowi opieki kalwińskiej, a zwłaszcza szpitalnej, słabość i krótkotrwałość reformacji. Zanim Kościół ten zaczął budować sieć szpitali i wypracowywać własny model opieki społecznej, jego pozycja została mocno osłabiona procesem rekatolicyzacji. W tej sytuacji za sukces należy uznać utrzymanie do czasów rozbiorowych sporej liczby szpitali na Litwie.

W przeciwieństwie jednak do Małopolski, w której kontrreformacja w ciągu XVII w. niemal całkowicie wyeliminowała innowierców z życia religijnego i spowodowała powrót szlachty do katolicyzmu, na Litwie wyłom w szeregach Jednoty był niewielki. Nawet, gdy zabrakło opieki ze strony potężnych Radziwiłów birżańskich, wymarłych w linii męskiej w 1669 (śmierć Bogusława), organizacja kościelna, a więc także zapewne szpitale oraz dobroczynność korzystały z oparcia innych rodów zamożnej szlachty, z tzw. kolektywnego mecenatu Jednoty ${ }^{196}$. Nie ułatwiał też rozwoju długofalowych działań opiekuńczych brak mocnych i stabilnych struktur kościelnych. Zbory kalwińskie nie posiadały swej osobowości prawnej i praw publicznych, dochodziła do tego pełna zależność od patrona. Nieco lepszą sytuację w tym względzie posiadały zbory litewskie, natomiast szczególne upośledzenie prawne dotyczyło zborów małopolskich. Taki stan prowadził do bytowania w ciągłej niepewności, co w konsekwencji odbijało się negatywnie na funkcjonowaniu kościołów różnowierczych i związanych z nimi instytucji, między innymi szpitali ${ }^{197}$.

195 E. B a gińs k a, Działalność religijna, s. 216; Prawa i przywileje miasta $i$ dóbr ziemskich Zabludów w XV-XVIII wieku, opr. J. M a r o s z e k, Białystok 1999, dokument nr 31, s. 213.

196 M. Ko s m a n, Archiwum Jednoty Litewskiej, „Archeion”, 61, 1974, s. 82-83; T e n ż e, Protestanci i kontreformacja, s. 36-37.

197 S. T w o r e k, Działalność, s. 40-41; W. K r i e g s e i s e n, Ewangelicy polscy, s. 123. 


\section{Arianie}

Opieka społeczna u arian polskich (zboru mniejszego), którzy wykształcili się w 1565 r. z kalwinizmu polskiego (zbór większy) stanowi zagadnienie w zasadzie niezbadane. Biorąc pod uwagę głoszone przez nich hasła równości społecznej, a nawet przypadki wyzbywania się majątków i dóbr materialnych, można by przypuszczać, że skłonność i gotowość pomagania biednym oraz słabszym członkom wspólnoty była większa niż w innych Kościołach innowierczych. Szlacheccy przedstawiciele krańcowo-demokratycznego nurtu Braci Polskich (Grzegorz Paweł, Marcin Czechowic) twierdzili, że nie godzi się jeść chleba pochodzącego z potu ubogich poddanych, ani mieszkać w majętnościach, które nadano przodkom za rozlanie krwi. Dlatego zwracali się do przedstawicieli swojego środowiska, by sami podjęli prace i sprzedawali takie majętności, a pieniądze rozdali ubogim ${ }^{198}$.

Jednym $z$ bardziej widocznych objawów innego traktowania chłopów przez szlachtę ariańską były stosunkowo często dokonywane przez nią zbiorowe, jak i pojedyncze libertacje poddanych - zwolnienia $\mathrm{z}$ podatków oraz innych ciężarów i powinności ${ }^{199}$. W skali całego województwa krakowskiego zdarzały się one proporcjonalnie dużo częściej niż w środowisku pozostałej szlachty kalwińskiej czy to katolickiej $^{200}$. Więzy poddaństwa w posiadłościach szlacheckich Braci Polskich, w których panowały stosunki patriarchalne oparte na wyrozumiałości, były zapewne nieco lżejsze niż gdzie indziej. Pomimo pewnych nadużyć i postawy nie zawsze zgodnej z głoszonymi ideałami ${ }^{201}$

\footnotetext{
198 Najstarsze synody arian polskich, wyd. S. Z a c h o r o w s k i, „Reformacja w Polsce”, 1, nr 3, s. 233; A. K o s s o w s k i, Protestantyzm w Lublinie, s. 37; S. T w o r e k, Raków ośrodkiem radykalizmu ariańskiego 1569-1572, Kraków 1968, IV, s. 57. 199 Zob. np. S. T wore k, Zbór lubelski i jego rola $w$ ruchu ariańskim $w$ Polsce w latach 1570-1598, „Annales Universitatis Mariae Curie-Skłodowska”, F. S e c t i o, 10, 1955, s. 31; T e n ż e, Zbór lubelski i jego rola $w$ ruchu ariańskim $w$ Polsce $w$ XVIXVII wieku, Lublin 1966, s. 49-50; W. U r b a n, Praktyczna działalność Braci Polskich wobec chłopów, „Odrodzenie i Reformacja w Polsce”, 5, 1960, s. 110 i nast.

${ }^{200}$ W. U r b a n, Praktyczna działalność, s. 110; T e n ż e, Skład społeczny i ideologia sejmiku krakowskiego w latach 1572-1606, „Przegląd Historyczny”, XLIV, 1953, s. 319, 333; S. S z c z o t k a, Z dziejów chłopów polskich, Warszawa 1951, s. 120-121; T e ṅ̇e, Zwalnianie chtopów z poddaństwa $w$ województwie krakowskim $w$ latach 1572-1794, „Czasopismo Prawno-Historyczne”, 3, 1951.

${ }^{201}$ Cztery broszury polemiczne z początku XVII wieku, opr. H. G ó r s k a, L. S z c z u c k i, K. W i 1 c z e w s k a, Warszawa 1958. Zob. zwłaszcza „Obrona dyjalogu”, s. 149-257.
} 
zarówno właściciele ziemscy, jak i ministrowie ariańscy odróżniali się korzystnie od właścicieli dóbr oraz duchownych innych wyznań ${ }^{202}$. Wywodzona z Ewangelii ariańska ideologia egalitaryzmu, w tym zalecana polityka szlachty wobec chłopów, nie może jednak być traktowana jako właściwa opieka społeczna, choć niewątpliwie bliska była idei miłosierdzia.

W gminach ariańskich występowały także tradycyjne przytułki dla ludzi starych i nie zdolnych do pracy. Na 52 zborów ariańskich istniejących w pod koniec XVI w. na terenie Małopolski ${ }^{203}$, tylko odnośnie dwóch, na Sądecczyźnie, posiadamy informacje o szpitalach Braci Polskich. Jeden z nich - ,przytułek dla wiekowych” - wzniesiono w roku 1567/8 w Nowym Sączu, za rzeką Kamienicą, na miejscu zwanym później „Piekłem”"204. Również w pobliskim siedlisku plebejuszy antytrynitarskich, w Tropiu nad Dunajcem, zwolenniczka arianizmu dziedziczka Dorota Robkowska (alias Grabieńska) w początkach XVII w. (1608) utrzymywała dla nich przytułek, służący katolikom i arianom. Został on ufundowany jeszcze przed przejęciem parafii przez innowierców, ok. 1560 r. przez katolickiego szlachcica Łyczkę. Po odzyskaniu po 40 latach kościoła parafialnego przez katolików, przytułek powrócił do dawnych właścicieli. Trudno powiedzieć, czy były to jedyne ariańskie domy opieki na ziemiach Rzeczypospolitej, jednakowoż sądzić można, że inicjatyw takich mogło być więcej. Pewnym jest natomiast, że oprócz szpitala w Tropiu, na terenie Sądecczyzny nie było żadnego innego przytułku ariańskiego ${ }^{205}$.

Statystycznie wśród arian dominowała szlachta, jednak skład społeczny prawie 30\% zborów (47 spośród 171) miał charakter mieszczański, szczególnie rzemieślniczy. Ponadto zbory mieszczańskie były o wiele większe od szlacheckich ${ }^{206}$. Jakie więc formy opieki proponowali swoim starym i biednym współwyznawcom mieszczańskim bogaci patroni Kościoła ariańskiego. Zapewne otaczali ich analogiczną opieką, jak kalwini swoich współbraci w wierze.

\footnotetext{
${ }^{202}$ W. U r b a n, Praktyczna działalność, s. 113, 119, 124-125.

${ }^{203}$ M. K o s m a n, Litewska Jednota, s. 6.

204 J. T a z b i r, Arianizm w Sądecczyźnie, „Rocznik Sądecki”, 8, 1967, s. 313, 321.

205 B. K u m o r, Szpitalnictwo w Sądecczyźnie w okresie przedrozbiorowym, „Rocznik Sądecki”, 10, 1969, s. 222-223, 233; Zob. też: J. T a z b i r, Arianizm w Sądecczyźnie, 321; W. U r b a n, Chłopi wobec reformacji w Małopolsce, Kraków 1959, s. 180 i nast.

${ }^{206}$ K. Le p s z y, A. K a m iń s k a, Geneza i program, s. 130-131.
} 
Można przypuszczać, że podobnie jak kalwinizmie, również w gminach ariańskich dbano o starych, wysłużonych ministrów i o pozostałe po nich wdowy oraz sieroty. Problem ten nie był jednak w takim stopniu obecny na synodach ariańskich, jak to miało miejsce u braci ze ,zboru większego". Trudno sobie wyobrazić, by „orędownicy i prekursorzy” doktryny braterskiej miłości, w praktyce mogli zapomnieć o różnych kategoriach potrzebujących ze swojej wspólnoty. Takie wsparcie i samopomoc było im bardzo niezbędne po wydaniu w 1658 r. dekretu banicyjnego, skazującego arian na wygnanie. $\mathrm{Ci}$, którzy nie przeszli na katolicyzm, a pozostali w kraju, wyznając kryptoarianizm, w sposób szczególny zdani byli na pomoc z zewnątrz, często zagraniczną. Nie byli też Bracia Polscy w komfortowej sytuacji w okresie wcześniejszym; zwalczani za ideologiczny radykalizm przez kościół katolicki i pozostałe wyznania reformowane, musieli liczyć przede wszystkim na własne działania dobroczynne.

Opieka społeczna i działalność dobroczynna arian polskich, z natury wynikająca $\mathrm{z}$ ich humanitarnej filozofii, nie wypracowała stabilnych struktur, zarówno szpitalnych oraz poza instytucjonalnych, jak w innych konfesjach innowierczych. Nie dorównywała nawet opiece występującej w Kościele Braci Czeskich, w przeciwieństwie do arian bardziej zintegrowanym i posiadającym mocnych protektorów. Bracia Polscy niejednolici programowo, czujący zagrożenie i nieufność ze strony „bratnich” Kościołów, nie mogli prowadzić spójnej, regulowanej na synodach polityki opiekuńczej. Ich działania charytatywne nie były systemowe, przybierały oblicze bardziej indywidualne i spontaniczne. Byli oni też najkrócej działającą w Rzeczypospolitej grupą wyznaniową, co również nie sprzyjało tworzeniu lepszych i skuteczniejszych akcji dobroczynnych.

\section{Bracia czescy}

Spośród wyznań protestanckich, najmniej licznym na terenach Rzeczypospolitej byli bracia czescy. Pierwsi ich przedstawiciele jako emigranci z Czech, przybyli do Leszna w 1516 r. ${ }^{207}$. Na większą skalę osiedlili się dopiero w Wielkopolsce w 1548 r., korzystając z protekcji możnych rodów, zwłaszcza Leszczyńskich i Ostrorogów. Głównymi ośrodkami nowej konfesji stały się Ostroróg i Leszno, będące wła-

${ }^{207}$ E. W i ś n i o w s k i, Bracia czescy, [w:] Encyklopedia Katolicka, t. 2, Lublin 1985, kol. 992 . 
snością wymienionych rodzin ${ }^{208}$. Największy rozkwit Jednoty na ziemiach Wielkopolski przypadł na siedemdziesiąte i osiemdziesiąte lata XVI w. ${ }^{209}$. W latach 1587-90 można stwierdzić istnienie trzydziestu 35 zborów, a przypuszczalnie kilkunastu dalszych. W sumie w XVI i na początku XVII w. Jednota miała w Wielkopolsce, z Kujawami i woj. sieradzkim, co najmniej 50 zborów, choć nie wszystkie egzystowały jednocześnie. Jedynym miastem, gdzie bracia czescy (ale nie Czesi) stanowili większość wyznaniową było Leszno ${ }^{210}$.

O działalności charytatywnej wspólnot braci czeskich niewiele wiadomo, choć kwestionariusz wizytacyjny z końca XVI w., nakazujący opisanie szpitala zborowego, świadczy, że również u nich przytułki stanowiły podstawową formę opieki społecznej. Istniały one przy każdym większym zborze Jednoty: w Poznaniu, Ostrorogu, Lesznie, Koźminku i Krotoszynie, ale także w niektórych mniejszych gminach czeskich na wsi: w Karminie, Parcicach, Weszkowie (Waszkowie). W Lesznie szpital założony przez braci czeskich, działał obok ewangelickiego szpitala $^{211}$. Wobec tego, że zbór poznański leżał poza murami miejskimi na gruncie stanowiącym własność Ostrorogów, wyjętym spod jurysdykcji miejskiej, można sądzić, że tam też mieścił się szpital. Podczas tumultu w 1605 r. został on poważnie zdewastowany $^{212}$. Jeden z najstarszych szpitali braci czeskich istniał w Ostrorogu. Zbudowano go już w pierwszej połowie XVII w., skoro ocalał jako jeden z nielicznych obiektów podczas pożaru miasta w $1555 \mathrm{r}^{213}$.

Wiadomości o szpitalach Jednoty polskiej są nadzwyczaj szczątkowe. Sądząc po szlacheckiej strukturze społecznej wspólnoty, można

\footnotetext{
${ }^{208}$ H. G mi te r e k, Bracia czescy a kalwini, s. 6, 12; E. W i ś n i ow s k i, Bracia czescy, kol. 994; K. Le p s z y, A. K a m i ń s k a, Geneza i program społeczny radykalnego nurtu Braci Polskich, „Odrodzenie i Reformacja w Polsce”, 1, 1956, s. 44.

209 J. D w or z a c z k ow a, Reformacja $i$ kontrreformacja, s. 314; T a ż, Sytuacja materialna duchowieństwa braci czeskich w Polsce do początków XVII wieku, „Odrodzenie i Reformacja w Polsce", 29, 1984, s. 139.

210 J. D w or z a c z k ow a, Bracia czescy, s. 53, 56; T a ż, Reformacja i kontrreformacja, s. 216-217.

${ }^{211}$ I. D w o r z a c z k o w a, Bracia czescy, s. 53, 90, 156; J. B i e l e c k a, Bracia czescy w Lesznie Organizacja i działalność (1560-1817), ,Rocznik Leszczyński”, 2, 1978, s. 169.

212 J. D w or z a c z k o w a, Bracia czescy, s. 92.

213 M. S i p a yłło, Materiały do dziejów zboru w Ostrorogu, „Odrodzenie i Reformacja w Polsce", 13, 1968, s. 173; J. D w or z a c z k o w a, Z dziejów braci czeskich, Poznań 2003, s. 38.
} 
przypuszczać, że fundatorami tych placówek była bogata szlachta, posiadająca prawo własności w większości miast, w których funkcjonowały zbory braci czeskich ${ }^{214}$. Przykładowo szpital w Krotoszynie ufundowany został przez Barbarę z Rachemberków Rozrażewską ${ }^{215}$. Były to bardzo małe przytułki obliczone na kilka, górą kilkanaście osób, ponieważ same zbory były bardzo niewielkie. Największy z nich w Poznaniu liczył pod koniec XVI w. 200-500 osób. Nie wiadomo jacy pensjonariusze zamieszkiwali w przytułkach. Prawdopodobnie byli w nich zarówno przedstawiciele uboższej szlachty, wyznającej „czeską religię", jak też jej poddani, chłopi z okolicznych wsi ${ }^{216}$. Musiały zdarzać się próby wykorzystywania szpitali przez osoby nie zasługujące na pomoc, skoro wizytator miał sprawdzać, czy przebywający w szpitalach ubodzy są ,godni jałmużny"217. Za założenie i prowadzenie szpitala odpowiadała wspólnota zborowa, czego przykładem był zbór w Lesznie, który przeznaczając na cele opiekuńcze wysokie kwoty, utrzymywał dom opieki, szkołę z wyżywieniem dla ubogich dzieci oraz udzielał stałych zapomóg wdowom i sierotom. W protokoły leszczyńskiej rady gminy wpisywano wykazy wdów i sierot, a sumy pieniężne na nie stanowiły stały punkt wydatków zborowych ${ }^{218}$.

Instytucjonalna opieka szpitalna stanowiła najważniejszą, ale nie jedyną formę pomocy potrzebującym w gminach braci czeskich. Synody nakazywały, by duchowni (ministrowie), którzy mieli większe dochody oddawali nadwyżkę na kształcenie młodzieży i wsparcie ubogich $^{219}$. Ogłoszone w 1573 r. i później wielokrotnie powtarzane Powinności ministrów nakazywały m.in. „nie szukać niedozwolonych zysków, nie nosić drogich szat, opiekować się ubogimi..."220. Obowiązek świadczenia pomocy potrzebującym w zborach Jednoty spoczywał też na seniorach świeckich, których na synodzie w 1560 r. wybrano

\footnotetext{
${ }^{214}$ H. G m i te re k, Bracia czescy a kalwini, s. 61-62; A. W y r o b i s z, Rola miast prywatnych w Polsce w XVI i XVII wieku, „Przegląd Historyczny”, 65, 1974, z. 1, s. 21.

215 J. D w or z a c z k o w a, Bracia czescy, s. 90.

${ }^{216}$ H. G m i t e r e k, Bracia czescy a kalwini, s. 61.

217 J. D w or z a c z k o w a, Bracia czescy, s. 90.

218 J. B i e l e c k a, Bracia czescy, s. 169-169 i inne; W. K r i e g s e i s e n, Ewangelicy polscy, s. 127.

219 J. D w o r z a c z k o w a, Bracia czescy, s. 68.

220 J. D w or z a c z k o w a, Reformacja $i$ kontreformacja, s. 208-209; T a ż, Sytuacja materialna, s. 135; J. D w o r z a c z k o w a, Bracia czescy, s. 69.
} 
dziewięciu, po trzech dla województwa poznańskiego i kaliskiego oraz Kujaw $^{221}$. W ramach wielorakich zadań opiekowali się oni wdowami, sierotami i ubogimi, mieli też pilnować, aby dobra kościelne przeznaczano m.in. na wsparcie ubogich ${ }^{222}$.

W większości zborów istniała odrębna funkcja opiekuna sierocego. Już organizując pierwszy zbór w Poznaniu powołano „świeckich sędziów zborowych” (zwanych później „starszymi kościelnymi”), którzy mieli nadzorować opiekunów sierot i opiekować się wędrownymi czeladnikami. Gorliwą troską zalecano otaczać w kościele braci czeskich starych ministrów i wdowy po zmarłych księżach ${ }^{223}$. Te ostatnie starano się jak najszybciej usunąć z plebani, aby zrobić miejsce dla następcy. W 1577 r. pojawił się projekt stworzenia „cenobiów”, gdzie utrzymywane byłby wdowy i sieroty po ministrach. W praktyce zarówno starzy ministrowie, jak i wdowy były często zaniedbywanie w polskiej Jednocie. Wobec tego, od 1640 r. zaczęto urządzać w zborach regularne zbiórki na wdowy i sieroty $^{224}$. Na synodzie w Miłosławiu w 1607 r. wydano nakaz zapewnienia pastorowi uczciwego uposażenia i wsparcia w razie choroby lub starości. We wspólnotach braci czeskich wykorzystywano też na działalność dobroczynną fundusze z ofiar składanych przez wiernych do karbony kościelnej. W zborze w Karminie zanotowano np. na początku XVII w. wydatek na cel charytatywny, mianowicie na odwiezienie do krewnych chorego ubogiego ${ }^{225}$.

Członkowie i władze omawianego wyznania wykazywali dużą wrażliwość i współczucie w stosunku do swoich współbraci, których dotykały grasujące epidemie. Ich synod w 1560 r. nakazał, aby z chorymi na zarazę nie postępować „z okrutnością”, ale zaopatrywać ich w lekarstwa, żywność oraz przyjmować do „gościńców”. To pod wpływem tych ustaw synodalnych rada miejska Poznania zarządziła w 1568 r. w czasie pomoru, iż domy, w których znajdują się zarażeni, powinny być zamknięte, jednakże izolowanym w nich osobom należało

\footnotetext{
${ }^{221}$ J. D w o r z a c z k o w a, Bracia czescy, s. 51-52.

222 J. B i e le c ka, Bracia czescy, s. 169; J. D w or z a c z k ow a, Bracia czescy, S. $51-52$.

223 J. D w o r z a c z k ow a, Bracia czescy, s. 51, T a ż, $Z$ dziejów, s. 74.

224 J. D w o r z a c z k o w a, Bracia czescy, s. 68, 142; T a ż, Z dziejów braci czeskich, s. 74; T a ż, Sytuacja materialna, s. 135.

225 J. D w or z a c z k ow a, Z dziejów braci, s. 65, T a ż, Zbór braci czeskich $w$ Karminie, „Odrodzenie i Reformacja w Polsce”, 13, 1968, s. 188.
} 
dostarczać jedzenie oraz odpowiednie medykamenty ${ }^{226}$. W początkach XVIII w. bracia czescy utracili znaczenie z powodu wynaradawiania się członków gmin i upodobniania się do Kościołów reformowanych. Posiadali wtedy zaledwie 18 zborów $^{227}$, a zapewne jeszcze dużo mniej szpitali - przytułków.

W porównaniu do katolików opieka społeczna u protestantów miała bardziej świecki wymiar. Dotyczyło to szczególnie ewangelików augsburskich, u których ciężar pomocy nad potrzebującymi przejęły miasta. Jednocześnie luteranie całkowicie zanegowali koncepcję chrześcijańskiego rozdawnictwa jałmużny i do minimum ograniczyli pole do działań typowo charytatywnych. Z kolei we wspólnotach kalwińskich, również ariańskich i braci czeskich, decydującą rolę we wspomaganiu swoich pauperes, odgrywali możni protektorowie zborów i podległych im ziem. U nich jednak zachowano jałmużnę jako ważny środek działań dobroczynnych, zalecany również na synodach kalwińskich.

\section{Bibliografia}

\section{Źródła archiwalne}

Archiwum Archidiecezjalne w Poznaniu (AAP)

sygn. AV 18, Visitatio archidiaconatus Posnanensis [...] a Nicolao Zala-

szowski archidiacono Posnaniensi. Anno Domini 1695-1696 expedita; sygn. AV 33, Visitatio generalis archidiconatus Śremensis: Śmigiel, Wschowa, Koźmin, Krobia aucthoritate Andreae Stanislai Młodziejowski et Antonii Onuphri Okęcki episcoporum Posnaniensium [...] Anno Domini 1777-1783 expedita.

\section{Archiwum Katolickiego Uniwersytetu Lubelskiego}

Bak M. T., Dom sierot w Ustroniu w latach 1735-1787, Lublin 2010, mps.

\section{Biblioteka Uniwersytetu Mikołaja Kopernika w Toruniu}

K. Pękacka-Falkowska, Wielka epidemia chorób zakaźnych w nowożytnym

Toruniu. Wielka zaraza $w$ trakcie III wojny pótnocnej jako fakt totalny, Toruń 2012, mps.

226 J. D w o r z a c z k o w a, Bracia czescy, s. 90.

${ }^{227}$ E. W i śn n o w s k i, Bracia czescy, kol. 994. 


\section{Opracowania}

Akta synodów prowincjonalnych Jednoty Litewskiej 1611-1625, Monumenta

Reformationis Poloniae et Lituaniae, Seria IV, Zeszyt II, Wilno 1915.

Akta synodów prowincjonalnych Jednoty Litewskiej 1626-1637, opr. M. Liedke,

P. Guzowski, Warszawa 2011,

Akta synodów różnowierczych w Polsce (1569-1632), opr. M. Sipayłł, t .4, Warszawa 1997.

Akta synodów różnowierczych w Polsce (1550-1559), opr. M. Sipayłł, t. 1,

Warszawa 1966. Akta synodów różnowierczych w Polsce (1560-1570), opr. M. Sipayłło, t. 2, Warszawa 1972. Akta synodów różnowierczych w Polsce (1550-1559), opr. M. Sipayłł, t. 3, Warszawa 1983.

Augustyniak U., Dwór i klientela Krzysztofa Radziwitła 91585-1640). Mechanizmy patronatu, Warszawa 2001.

Augustyniak U., „Stary stuga” jako przedmiot badań nad klientelizmem magnackim na Litwie w XVII wieku, „Kwartalnik Historii Kultury Materialnej", 58, 2010, $\mathrm{nr} 1$, s. 77.

Augustyniak U., Testamenty ewangelików reformowanych $w$ Wielkim Księstwie Litewskim, Warszawa 1992

Bagińska E., Działalność religijna Radziwiłtów birżańskich $w$ dobrach podlaskich w XVII wieku, „Studia Podlaskie”, 12, 2002, s. 205-228.

Bartel O., Marcin Luter w Polsce, „Odrodzenie i Reformacja w Polsce”, 7, 1962, s. 27-50.

Bem K., Zbór w Piaskach koło Lublina, „Odrodzenie i Reformacja w Polsce", 43, 1999, s. 85-98.

Bielecka J., Bracia czescy w Lesznie Organizacja i działalność (1560-1817), „Rocznik Leszczyński”, 2, 1978, s. 153-173.

Bogucka M., Dom pracy w Gdańsku w XVII wieku, „Kwartalnik Historii Kultury Materialnej”, 34, 1986, nr 2, s. 265-269.

Bogucka M., Organizacja szpitalnictwa w Gdańsku w XVI-XVII wieku, [w:] Szpitalnictwo w dawnej Polsce, red. M. Dąbrowska, J. Kruppé, Warszawa 1998, s. 137-152.

Bogucka M., Urząd Zapasów a konsumpcja Gdańska w pierwszej połowie XVII wieku, „Kwartalnik Historii Kultury Materialnej”, 18, 1970, nr 2, s. 255-260.

Budzyński Z., Dzieje opieki spotecznej w ziemi przemyskiej i sanockiej (XVXVIII w.), Przemyśl-Kraków 1987.

Byrtek E., Miłosierdzie i opieka społeczna w osiemnastowiecznym pietyźmie, [w:] Charitas. Miłosierdzie i opieka społeczna $w$ ideologii, normach postepowania i praktyce społeczności wyznaniowych $w$ Rzeczypospolitej XV-XVIII wieku, red. U. Augustyniak, A. Karpiński, Warszawa 1999. 
Cackowski S., Terytorium, ludność, władze miejskie, [w:] Historia Torunia, red M. Biskup, t. 2, cz. 2, W czasach renesansu, reformacji $i$ wczesnego baroku (1548-1660), Torun 1994, s. 7-45.

Chyła D., Opieka społeczna na Kujawach w latach 1577-1792, Lublin 2015.

Cieślak E., Obraz spoleczeństwa gdańskiego i jego życia codziennego, [w:] Historia Gdańska, t. III/1: 1655-1793, pod red. E. Cieślaka, Gdańsk 1993.

Cztery broszury polemiczne z początku XVII wieku, opr. H. Górska, L. Szczucki, K. Wilczewska, Warszawa 1958.

Dola K., Szpitale średniowieczne Śląska. Rozwój historyczny, „Rocznik Teologiczny Śląska Opolskiego", 1, 1968, s. 239-291.

Drzewiecki B., Pękacka-Falkowska K., O protestanckiej mitości bliźniego czyli toruńska Ordinanz des Vorsteher-Amts wegen des Haltungen von die Armut z 1665 roku, „Zapiski Historyczne”, 77, 2012, z. 3, s. 51-66.

Dworzaczkowa J., Bracia czescy w Wielkopolsce w XVI i XVII wieku, Warszawa 1997.

Dworzaczkowa J., Reformacja i kontrreformacja w Wielkopolsce, Poznań 1995.

Dworzaczkowa J., Sytuacja materialna duchowieństwa braci czeskich w Polsce do poczattów XVII wieku, „Odrodzenie i Reformacja w Polsce”, 29, 1984, s. 119-144.

Dworzaczkowa J., Z dziejów braci czeskich, Poznań 2003.

Dworzaczkowa J., Zbór braci czeskich w Karminie, „Odrodzenie i Reformacja w Polsce", 13, 1968, s. 185-204.

Dybaś D., Burmistrz reformator. Wokót programu reformatorskiego Henryka Strobanda, „Zapiski Historyczne”, 66, 2001, z. 4, s. 29-43.

Dygdała J., Organizacja, skład i funkcjonowanie samorządu miejskiego, [w:] Historia Torunia, t. 2, cz. III, Między barokiem a oświeceniem, red. M. Biskup, Torun 1996.

Dygdała J., W cieniu głębokich konfliktów wyznaniowych, [w:] Historia Torunia, t. 2, cz. III, Między barokiem a oświeceniem, red. M. Biskup, Toruń 1996, s. 175-205.

Frieck D., ,Libellus chamorum”. Protestancka elita mieszczańska a szlachta w Wilnie w XVII wieku, [w:] Litwa w epoce Wazów, red. W. Kriegseisen, Warszawa 2006, s. 239-256.

Geremek B., Litość i szubienica. Dzieje nędzy i miłosierdzia, Warszawa 1989.

Giedroyć F., Zapiski do dziejów szpitalnictwa w dawnej Polsce, Warszawa 1908.

Gierowski A., Pietyzm na ziemiach polskich (do połowy XVIII wieku), „Śląski Kwartalnik Historyczny Sobótka", 27, 1972, nr 2, s. 237-261.

Glemma T., Stosunki kościelne w Toruniu w XVI i XVII stuleciu na tle dziejów kościelnych Prus Królewskich, „Roczniki Towarzystwa Naukowego w Toruniu", 42, 1934. 
Gmiterek H., Bracia czescy a kalwini w Rzeczypospolitej. Połowa XVI polowa XVII wieku, Lublin 1987.

Gmiterek H., Włodawa $w$ dziejach reformacji i kultury staropolskiej, [w:] Dzieje Włodawy, red. R. Szczygieł, E. Olszewski, Włodawa 1991.

Góralski Z., Szpitale na Lubelszczyźnie w okresie przedrozbiorowym w okresie przedrozbiorowym, Warszawa-Łódź 1982.

Gryko B., Sapieżyńskie fundacje szpitali jako przejaw miłosierdzia?, „Białostockie Teki Historyczne", 8, 2010, s. 56.

Herbst S., Toruńskie cechy rzemieślnicze. Zarys przeszłości, Toruń 1933.

Historia Torunia, t. 2, cz. I, U schytku średniowiecza $i$ w początkach odrodzenia 1454-1548, red. M. Biskup, Toruń 1992, s. 144-161.

Kaczor D., Dom poprawy (Zuchthaus) w Gdańsku w XVII-XVIII wieku, „Rocznik Gdański”, 56, 1996, s. 51-62.

Kaczor J., Protestantyzm $w$ powiecie radomskim $w$ XVI-XVIII wieku, [w:] Radom i region radomski $w$ dobie szlacheckiej Rzeczypospolitej, red. Z. Guldon, S. Zieliński, Radom 1996.

Karpiński A., Kobieta $w$ mieście polskim $w$ drugiej połowie XVI $i$ w XVII wieku, Warszawa 1996.

Kępa T., Luteranie $w$ wielkim Księstwie Litewskim, [w:] Kościół luterański na ziemiach polskich (XVI-XX w.) w czasach Rzeczypospolitej Obojga Narodów, red. J. Kłaczkow, Toruń 2012.

Kizik E., Śmierć w mieście hanzeatyckim w XVI-XVIII wieku. Studium z nowożytnej kultury funeralnej, Gdańsk 1998.

Kizik E., Zabezpieczenie finansowe wdów w Gdańsku w XVII-XVIII wieku, „Kwartalnik Historii Kultury Materialnej”, 58, 2010, nr 1, s. 87-100.

Kolendo-Korczak K., Propaganda reform burmistrza Henryka Strobanda $w$ dekoracji sali Rady z 1603 roku w Ratuszu Staromiejskim Torunia, „Zapiski Historyczne", 74, 2009, z. 3, s. 37-60.

Komaryńska H., Szpital Bonifratrów w Krakowie w XVII XVIII wieku, Lublin 2010.

Kopiczko A., Szpitalnictwo na Warmii w XVI-XVIII wieku, [w:] Szpitalnictwo w dawnej Polsce, red. M. Dąbrowska, J. Kruppé, Warszawa 1998, s. 97-107.

Korpalska W. K., Sześć wieków opieki zdrowotnej w Bydgoszczy, Toruń 2008.

Korpalska W. K., Szpitale w Bydgoszczy do końca XVIII wieku, „Archiwum Historii i Filozofii medycyny, 62, 1999, z. 4, s. 383-399.

Kosman M., Archiwum Jednoty Litewskiej, „Archeion”, 61, 1974, s. 81-101.

Kosman M., Litewska Jednota ewangelicko-reformowana od połowy XVII w. do 1939 r., Opole 1986.

Kosman M., Protestanci i kontrreformacja. Z dziejów tolerancji w Rzeczypospolitej XVI-XVIII wieku, Wrocław 1978. 
Kosman M., Sytuacja prawno-polityczna kalwinizmu litewskiego $w$ drugiej potowie XVII wieku, „Odrodzenie i Reformacja w Polsce”, 20, 1975, s. 82-110.

Kossowski A., Protestantyzm $w$ Lublinie $i$ w Lubelskiem $w$ XVI-XVII wieku, Lublin 1933.

Kriegseisen W., Ewangelicy polscy i litewscy w epoce saskiej (1696-1763), Warszawa 1996.

Kriegseisen W., Ewangelicy warszawscy w epoce saskiej, „Rocznik Warszawski”, 28, 1999, s. 15-31.

Kriegseisen W., Miłosierdzie czy opieka społeczna? Działalność opiekuńcza w Jednocie ewangelicko-reformowanej Wielkiego Księstwa litewskiego w XVIII wieku, [w:] Charitas. Milosierdzie i opieka społeczna w ideologii, normach postępowania i praktyce spoteczności wyznaniowych $w$ Rzeczypospolitej XV-XVIII wieku, red. U. Augustyniak, A. Karpiński, Warszawa 1999.

Kropidłowski Z., Formy opieki nad ubogimi w Gdańsku od XVI do XVIII w., Gdańsk 1992.

Kropidłowski Z., Organizacja dzieł miłosierdzia chrześcijańskiego w Gdańsku w XVI-XVIII w., [w:] Charitas. Mitosierdzie i opieka spoleczna w ideologii, normach postępowania i praktyce spoleczności wyznaniowych w Rzeczypospolitej XV-XVIII wieku, red. U. Augustyniak, A. Karpiński, Warszawa 1999.

Kropidłowski Z., Realizacja miłosierdzia chrześcijańskiego $w$ działalności kas samopomocowych cechów gdańskich (XVI-XVIII w.), „Studia Gdańskie", 8, 1992, s. 127-149.

Kropidłowski Z., Samopomoc w korporacjach rzemieślniczych Gdańska, Torunia i Elblaga (XIV-XVIII wiek), Gdańsk 1997.

Kumor, Szpitalnictwo w Sądecczyźnie w okresie przedrozbiorowym, „Rocznik Sądecki”, 10, 1969, s. 221-265.

Lepszy K., Kamińska A., Geneza i program społeczny radykalnego nurtu Braci Polskich, „Odrodzenie i Reformacja w Polsce”, 1, 1956, s. 33-70.

Lewicki J., Stosunki wyznaniowe w wielkopolskiej części diecezji poznańskiej $w$ drugiej połowie XVIII w., [w:] Z badań nad dziejami zakonów i stosunków wyznaniowych w Polsce, red. E. Wiśniowski, Lublin 1984, s. 89-138.

Litak S., Historia wychowania do wielkiej rewolucji francuskiej, Kraków 2004.

Łukaszewicz J., Dzieje Kościołów wyznania helweckiego w dawnej Małej Polsce, Poznań 1853.

Łukaszewicz J., Krótki opis historyczny kościołów parochialnych, kościołów, kaplic, klasztorów, szkółek parochialnych, szpitali i innych zaktadów dobroczynnych dawnej diecezji poznańskiej, t. 1, Poznań 1958.

Łukaszewicz J., Wiadomości historyczne o dysydentach $w$ Poznaniu $w$ XVI i XVII wieku, Poznań 1832. 
Maroszek J., Dzieje zboru kalwińskiego w Zabludowie w latach 1608-1868, [w:] Mój Kościól w historię wpisany. Ksiega pamiątkowa dedykowana Księdzu Profesorowi Tadeuszowi Krahelowi, red. T. Kasabuła, A. Szot, Białystok 2007, s. 274-310.

Maroszek J., Wileńskie przytutki - szpitale w XVI-XVIII wieku, [w:] Cała historia to dzieje ludzi... studia z historii spotecznej ofiarowane prof. Andrzejowi Wyczańskiemu w 80. rocznice urodzin i 55-lecie pracy naukowej, red. C. Kukla, Białystok 2004, s. 191-218.

Merczyng H., Zbory i senatorowie protestanccy $w$ dawnej Rzeczypospolitej, Warszawa 1904.

Molenda D., Dzieje Olkusza do 1795 r., [w:] Dzieje Olkusza i regionu olkuskiego, red. F. Kiryk, R. Kołodziejczyk, Warszawa 1978, t. 1, s. 147-340.

Molenda D., Opieka zdrowotna i społeczna górników olkuskich w XV-XVIII wieku, [w:] Szpitalnictwo w dawnej Polsce, red. M. Dąbrowska, J. Kruppé, Warszawa 1998, s. 55-67.

Najstarsze synody arian polskich, wyd. S. Zachorowski, „Reformacja w Polsce”, $1, \mathrm{nr} 3$.

Neugebauer K., Rys historyczny Szpitala Ewangelickiego w Warszawie, Warszawa 1931.

Otto L., Przyczynek do historii zboru ewangelicko-augsburskiego warszawskiego 1650-1781, Warszawa 1881.

Partyka W., Opieka społeczna w Ordynacji Zamojskiej w XVII-XVIII wieku, Lublin 2008.

Pazzini A., L'ospedale nei secoli, Roma 1958.

Pękacka-Falkowska K., Profilaktyka przeciwdżumowa w nowożytnym Toruniu na przyktadzie działań administracyjnych i leczenia, Toruń 2009.

Pękacka-Falkowska K., Toruńska medycyna i farmacja wobec powietrza morowego w świetle niemieckojęzycznego starodruku medycznego z 1709 roku, „Klio. Czasopismo poświęcone dziejom Polski i powszechnym”, 11, 2008, s. 53-88.

Podgórska-Klawe Z., Szpitale warszawskie 1388-1945, Warszawa 1975.

Poloczkowa B., Dokumenty Domu Sierot w Ustroniu, „Pamiętnik Cieszyński”, 14, 1999, s. 94-109.

Poloczkowa B., Fundacje społeczne mieszkańców Cieszyna XV-XX w., „Pamiętnik Cieszyński”, 6, 1993, s. 25-48.

Prawa i przywileje miasta i dóbr ziemskich Zabłudów w XV-XVIII wieku, opr. J. Maroszek, Białystok 1999.

Rosiak S., Bonifratrzy w Wilnie (1635-1835-1924). Szkice z dziejów opieki spolecznej w Wilnie, Wilno 1928.

Salmonowicz S., Kultura umystowa Torunia $w$ dobie renesansu, reformacji i wczesnego baroku, [w:] Historia Torunia, red. M. Biskup, t. 2, cz. 2, W cza- 
sach renesansu, reformacji i wczesnego baroku (1548-1660), Toruń 1994, s. $169-256$.

Salmonowicz S., O reglamentacji obyczajowości mieszczańskiej w Toruniu wXVI-XVIII wieku (zakres problematyki), „Zapiski Historyczne”, 41, 1976, z. 3, s. 87-103.

Salmonowicz S., Życie luteranów toruńskich, w XVII i XVIII wieku, „Odrodzenie Reformacja w Polsce", 34, 1989, s. 115-130.

Sipayłło M., Materiały do dziejów zboru w Ostrorogu, „Odrodzenie i Reformacja w Polsce", 13, 1968, s. 169-184.

Sokół S., Historia gdańskiego cechu chirurgów 1445-1820, WrocławWarszawa 1957.

Sokół S., Historia gdańskiego cechu chirurgów, Wrocław 1951.

Spiess L., Opis szpitala ewangelickiego w Warszawie, [w:] Rys historycznostatystyczny szpitali i innych zakładów dobroczynnych $w$ Królestwie Polskim, t. 2, Warszawa 1872.

Surdacki M., Opieka społeczna w Wielkopolsce Zachodniej w XVII-XVIII wieku, Lublin 1992.

Surdacki M., Protestanci a rozwój szpitali w Wielkopolsce Zachodniej w XVII i XVIII wieku, „Odrodzenie i Reformacja w Polsce”, 36, 1991, s. 193-208.

Surdacki M., Sieć szpitali tacińskich w Rzeczypospolitej w XVI-XVIII wieku, „Nasza Przeszłość”, 123, 2015, s. 133-184.

Surdacki M., Urzędów w XVII - XVIII wieku. Miasto-Społeczeństwo-Życie codzienne, Lublin 2007.

Szarszewski A., ,,Tablica jałmużnicza” Antona Möllera z Kościoła Mariackiego w Gdańsku. Społeczna geneza zabytku, „Rocznik Gdański”, 66, 2006, s. 85-99.

Szarszewski A., Najstarsze księgi rachunkowe szpitali gdańskich, Toruń 2005.

Szarszewski A., Ordynacje i instrukcje szpitala św. Lazarza, Szpitala na Zapleczu oraz Domu dla Chorych Zakaźnie w Gdańsku XVII-XVIII w. Toruń 2005.

Szarszewski A., Ordynacje i statuty szpitali gdańskich XV-XIX w., Toruń 2004.

Szarszewski A., Sprawy szpitali i sierocińców w aktach prawnych Rady Miasta Gdańska XVI-XVIII w., Torun 2006.

Szarszewski, Życie codzienne w szpitalu św. Jakuba w Gdańsku w XVI-XVIII w., [w:] Szpital i kościót św. Jakuba. 600 lat fundacji gildii szyprów w Gdańsku, red. A. Sroka, Toruń 2009.

Szczotka S., Z dziejów chłopów polskich, Warszawa 1951.

Szczotka S., Zwalnianie chłopów z poddaństwa w województwie krakowskim w latach 1572-1794, „Czasopismo Prawno-Historyczne”, 3, 1951.

Tazbir J., Arianizm w Sadecczyźnie, „Rocznik Sądecki”, 8, 1967.

Tworek S., Działalność oświatowo-kulturalna kalwinizmu małopolskiego, Lublin 1970. 
Tworek S., Materiały do dziejów kalwinizmu w Wielkim Księstwie Litewskim w XVII wieku, „Odrodzenie i Reformacja w Polsce”, 14, 1969, s. 199-215.

Tworek S., Raków ośrodkiem radykalizmu ariańskiego 1569-1572, Kraków 1968.

Tworek S., $Z$ zagadnień organizacji zborów kalwińskich $w$ Matopolsce w XVI-XVII wieku, „Rocznik Lubelski”, 8, 1965, s. 63-75.

Tworek S., Z zagadnień ruchu kalwińskiego w Małopolsce, „Rocznik Lubelski", 10, 1967, s. 153-170.

Tworek S., Zbór lubelski i jego rola $w$ ruchu ariańskim $w$ Polsce $w$ latach 1570-1598, „Annales Universitatis Mariae Curie-Skłodowska”, Sectio F., 10, 1955, s. 21-48.

Tworek S., Zbór lubelski i jego rola $w$ ruchu ariańskim $w$ Polsce $w$ XVI-XVII wieku, Lublin 1966.

Urban W., Chtopi wobec reformacji w Małopolsce, Kraków 1959.

Urban W., Praktyczna działalność Braci Polskich wobec chłopów, „Odrodzenie i Reformacja w Polsce", 5, 1960, s. 109-126.

Urban W., Reformacja wśród chłopów w Oświęcimskim, „Odrodzenie i Reformacja w Polsce", 2, 1957, s. 151-176.

Urban W., Skład społeczny i ideologia sejmiku krakowskiego w latach 15721606, „Przegląd Historyczny”, XLIV, 1953, s. 309-333.

Wachholz L., O szpitalach innowierców w Krakowie. Szkic historyczny, „Archiwum Filozofii i Historii Medycyny, 2, 1925, s. 169-176.

Wachholz L., Szpitale krakowskie 1220-1920, t. 1, Kraków 1921.

Wachholz L., $Z$ dziejów zboru ewangelickiego w Krakowie, „Reformacja w Polsce", 1, 1921, nr 4.

Wajsblum M., O wyznaniowym obliczu protestatntyzmu polskiego i jego postawach spotecznych, [w:] Pamiętnik Zjazdu Naukowego im. Jana Kochanowskiego, Kraków 1931.

Wąsicki J., Miasta zachodniego pogranicza Wielkopolski 1793-1815, Poznań 1960.

Wijaczka J., Luteranie w Koronie od 1517 do 1795 r., [w:] Kościół luterański na ziemiach polskich (XVI-XX w.) w czasach Rzeczypospolitej Obojga Narodów, red. J. Kłaczkow, Toruń 2012.

Wiśniowski E., Bracia czescy, [w:] Encyklopedia Katolicka, t. 2, Lublin 1985, kol. 992-994.

Wizytacja biskupa sambijskiego z 1570 roku, wyd. J. Wijaczka, Torun 2005.

Wojtowicz J., Dzieje handlu, przemystu i rzemiosta, [w:] Historia Torunia, t. 2, cz. III, Między barokiem a oświeceniem, red. M. Biskup, Torun 1996.

Wyrobisz A., Rola miast prywatnych w Polsce w XVI $i$ XVII wieku, „Przegląd Historyczny", 65, 1974, z. 1, s. 21. 
Wyrozumski J., Początki opieki społecznej w górnictwie polskim, [w:] Prace $z$ dziejów Polski feudalnej, ofiarowane Romanowi Grodeckiemu w 70 rocznice urodzin, Warszawa 1960.

Zins H., Rewolta w Elblagu w 1525 r., „Zapiski Historyczne”, 12, 1956, z. 4, s. 7-50.

Żelewski R., Zaburzenia wyznaniowe w Krakowie. Okres przewagi różnowierców 1551-1573, „Odrodzenie i Reformacja w Polsce”, 6, 1961, s. 91-111. 